\title{
TRUSTS IN THE SETTING OF BUSINESS, COMMERCE, AND BANKRUPTCY*
}

\author{
DONOVAN W. M. WATERS**
}

\begin{abstract}
The trust has considerable potential as a business or commercial device. The author discusses the various ways in which the trust is presently being utilized, particularly in the bankruptcy setting. By examining afresh what the trust is, how it is created, and how it operates, we can better understand the significant developments which are expected in this area.
\end{abstract}

\section{INTRODUCTION}

Mr. Dean, Ladies and Gentlemen, it was with great pleasure that I accepted the invitation you extended to me to deliver the 1983 Weir Memorial Lecture, and my wife and I have certainly enjoyed the warmth of your considerable hospitality on this very special occasion. Indeed, one cannot be long in this Law School, hearing the tales of the past, and perusing the many portraits and photographs on your walls, without realising what a debt is owed to the long and devoted service of men like your first dean, John A. Weir. We of ten forget in these days of plenty how much was attained by the few law professors who staffed our schools in the early days between the two World Wars. They had so very little in the way of resources, and yet it was they whose dedication and unremitting hard work put together the institutions which later generations so much respected that they would fund them generously. Dean Weir died in harness; he literally wore himself out in the service of his school.

The topic for such an occasion as this should certainly stir the mind and quicken the blood, and it was therefore with some concern that it occurred to me after I had chosen it that my title this evening must seem singularly dull. Many find the law of trusts a pretty esoteric subject at the best of times, and bankruptcy might seem to lend a dispiriting note which esotericism could do without. However, I hope to be able to show you that this need not by any means be your final judgment. Not only within the last two decades has a new vitality seized the law of trusts, something which has given rise to much debate and learned writing, but coincidentally, almost unobserved by the legal literature, the trust has penetrated into areas of activity few in Canada associate with the trust. It now plays a significant part in the world of commerce, of investment, and of secured transactions. This is a development of a fascinating kind, because for the scholar it demonstrates the characteristics of the trust in a setting of relationships and expectations totally different from that of the administration of estates. For the practitioner it raises a distinct set of problem issues, which call for new thinking if those problems are to be solved.

* The material which follows is the full text of the Lecture. It was presented in synoptic form on the occasion of its oral delivery. I would like to express my gratitude to Professor Ronald C.C. Cuming and Professor Allison Dunham for the valuable contribution each made in connection with my research for this Lecture. However, the responsibility for everything here said is mine.

** Professor, Faculty of Law, University of Victoria. 


\section{THE INTERPLAY OF EQUITABLE AND LEGAL CONCEPTS}

\section{A. THE NEW EQUITY}

The new vitality in equity, of which I spoke, owes much to the extraordinary judicial career of Lord Denning, who retired in England last year. He was a fundamentalist in his conception of Equity; he saw doctrine as simply the handmaiden of justice and fairness, and during the nearly forty years he sat on the bench he was responsible for new directions in an astounding range of subject areas. Constructive trusts and resulting trusts, promissory estoppel and proprietary estoppel, unconscionability in contractual dealings, the right of the contractual licensee against his licensor and the third party, and the deserted wife's equity in relation to the matrimonial home; all these concepts, the last of them ultimately rejected in the final court of appeal, were woven into the tapestry of what seemed at times to be an almost homespun Equity.

Lord Denning had not only a sense that equity is morality, a vehicle for securing justice and fairness, he appeared to see rights in personam and rights in rem, without any particular distinction between them, as direct servants of the cause of justice between persons. I shall return to this in the closing part of the lecture, because I think that he, more than most, has suggested that the gulf that the nineteenth-century Austinians saw between such rights may not in fact exist. He appears to have concluded that obligation between two persons may well lend itself to a rationalisation whereby the obligatory right becomes a proprietary right for the party entitled to performance, and the duty a proprietary duty in the other. He naturally joined the ranks of those who find it unacceptable that the third party has no right to sue on a contract made between others for his benefit - indeed, Denning was prepared to find that the leading authority of Tweddle v. Atkinson ${ }^{1}$ was wrongly decided - but as the means wherewith to create proprietary rights out of personal obligation, he was also prepared to employ the resulting trust and the constructive trust. His prime and constant concern was whether this would bring about equity between the parties before him.

There is no doubt, as one looks at English, Canadian, Australian and New Zealand reported decisions, since 1965 in particular, that with his invocation of Equity's principles and precedents, very often in what appeared to be pure common law situations, Lord Denning caught the imagination of counsel and courts in all those countries. However, so far as the law of trusts is concerned, it is essentially in the area of matrimonial and family property disputes that Denning drew on the trust to produce his desired equity between the parties, and for his purpose there he naturally drew upon the remedial properties of resulting and constructive trusts. The manner of intervention of the trust into the world of business and commerce on the other hand, has been quite different. Though it has now made its way into that arena, it has arrived, so to speak, like the Trojan horse, under cover of night; it does not appear to have had any assistance from the new concern with equitable principles, and it is essentially the express trust that we find. 
Only recently has the scene threatened to change. In October, 1982, a Canadian appeal court avowedly adopted an equitable maxim in order to solve a commercial dispute involving trusts, ${ }^{2}$ and there is now the constructive trust based on unjust enrichment. ${ }^{3}$ This is still very new to the Canadian scene, and it has an obvious potential for making considerable inroads into commercial matters. In other words, equitable doctrines are now a factor to be reckoned with, and the considerations they entail are different from those at law.

What the express trust involves in its effects upon commercial relationships has yet to be appreciated, and the effect of the remedial constructive trust to be explored. Nevertheless, the early skirmishes with both suggest that not only practitioners, but Canadian courts and legislatures have a good deal of thinking to do if the trust is to contribute, rather than unsettle, perhaps bedevil, our commercial law in Canada.

\section{B. EQUITABLE PRINCIPLES: THE HOSTILITY OF THE COMMERCIAL COURTS}

It is precisely because of the more generalised nature of equity concepts that traditionally commercial courts have been hostile to the intervention of the trust. The notion that the third party purchaser is bound if he has actual or constructive notice of contractual terms and covenants earlier entered into between other parties concerning the property in question has not sat easy with commercial lawyers. The story of the fate of the Tulk v. Moxhay ${ }^{4}$ doctrine between its mid-nineteenth century origin and the First World War is well known. What started as a notice concept ended very like a new sort of easement, a much more restricted notion, well grounded in property law. And then there was Knight-Bruce L.J.'s famous dictum in De Mattos v. Gibson ${ }^{5}$ in 1858, where he said that "reason and justice" impose upon a third party purchaser with notice of previous contractual terms a restriction on the uses of the property acquired. Like another famous decision of the seventeenth century, ${ }^{6}$ it went down "like chopped hay" with succeeding decades of commercial lawyers, who rejected it out of hand. The Privy Council revived and applied it in the Strathcona case ${ }^{7}$ just after the First World War, when otherwise the courts had recently completed both the limitation of the effect of Tulk v. Moxhay and the disavowal of the notion that a stranger to a contract made between others for his benefit might sue as a trust beneficiary. Rarely has a decision been so pulverised by the pundits; no one it seemed, until recently, ${ }^{8}$ had a good word to say for Strathcona. In the early 1950s, while I was a law undergraduate, that decision was a

2. Re Winnipeg Mortgage Exchange Ltd. and Winnipeg Mortgage Holdings Ltd. (1982) 43 C.B.R. (N.S.) 119, [1983] 1 W.W.R. 213 (Man. C.A.).

3. Pettkusv. Becker [1980] 2 S.C.R. 834, 117 D.L.R. (3d) 257.

4. (1848) 2 Ph. 774, 41 E.R. 1143.

5. (1859) 4 De G. \& J. 276 at 282,45 E.R. 108.

6. Powell J. in Scattergoodv. Edge (1699) 12 Mod. 278 at 281, 88 E.R. 1320 at 1322, speaking of the decision in Pells v. Brown (1620) Cro. Jac. 590, 79 E.R. 504.

7. Lord Strathcona S.S. Co. Lid. v. Dominion Coal Co., Ltd. [1926] A.C. 108, [1925] All E.R. Rep. 87.

8. Post, n. 10. 
favourite fairground shy for student essay writing, and when later Diplock $J$. railed against it and refused to follow it in Port-Line Ltd. v. Ben Line Steamers Ltd. in $1958,{ }^{9}$ few would have thought his reaction was inappropriate. The fear, once again, was that $\mathrm{A}$, as a party to a contract who is entitled to equitable relief, would be said as a result to have acquired a proprietary right. As a constructive trust beneficiary, A could then enforce that right over the property in question against $C$, the third party purchaser from $B$, the party against whom the relief would be awarded. ${ }^{10}$ Instead of the personal right to damages for breach, or equitable relief with in personam connotations only, a generalised proprietary right would arise that would bind the subject property, even in the setting of commercial transactions. Such a thing was not to be tolerated. The law of constructive trusts had no place in the world of commerce.

This apprehension of the trust on the part of the commercial courts is also rooted in the distinct histories of common law and equity. It was not until the Judicature Act of $1873^{11}$ in England that law and equity were administered in the same courts by the same judges, and this has had a profound effect on the relationship between law and equity, both before 1873 and afterwards. Before 1873 for over two centuries, equity, both in the dictionary sense and the legal sense, was the creation and the exclusive province of the Court of Chancery; ${ }^{12}$ the bill of account, the equitable remedies, the equitable charge and the trust were known only by report to the judges of the common law courts. The forms of action governed the common law courts until their abolition in 1863, and it was in this totally different environment, consumed with procedural form, that the concepts of agency, debt, pledge and bailment were conceived and worked out. After 1873, judges of a unified court system had to

9. Port-Line Ltd.v. Ben Line Steamers Ltd. [1958] Q.B. 146, [1958] I All E.R. 787.

10. I.e., B contracts with $A$ for user rights over property owned by $A$; $A$ sells to $C$; $A$ seeks to enforce against $\mathrm{C}$ his rights to use the property.

Diplock J. said (id. at 165) that Knight-Bruce L.J.'s principle in De Mattos v. Gibson was dead, but that the later decision of Lord Chelmsford L.C. in that case was authority for the injunctive prevention of the third party from perpetrating the Lumleyv. Gye (18 E.R. 749) tort of knowingly procuring the breach of a contract between others. Noting this, an English court has recently described De Mattos v. Gibson as the equitable counterpart of the tort of interference with contractual relations. Moreover, Knight-Bruce L.J.'s words have been resurrected, and described with that meaning as good law. The Strathcona case, also, as an application of that meaning, was described as correctly decided. See Swiss Bank Corp. v. Lloyds Bank Ltd. [1979] Ch. 548 at 572-575, [1979] 2 All E. R. 853 at 871-874. Browne-Wilkinson J.'s entire analysis of the state of the case law where the third party takes property expressly subject to, or with actual (or constructive) notice of, an existing contract between others, makes rewarding reading. However, in consonance with past judicial opinion, he appears to take a hesitant and conservative position with regard to the constructive trust. On other grounds his decision was reversed on appeal, [1982] A.C. 584, [1980] 2 All E.R. 419 (C.A.), a judgment upheld in the House of Lords, [1982] A.C. 584, [1981] 2 All E.R. 449. For commentary, see (1982) 98 L.Q.R. 279 (Simon Gardner), and (1982) 45 Mod. L.R. 241 (Nili Cohen-Grabelsky).

11. $36 \& 37$ Vict., c. 66 .

12. Though an equity jurisdiction was also exercised in the Court of Exchequer Chamber between the fifteenth century and 1842, when it was abolished and transferred to the Court of Chancery; Holdsworth, W., A History of English Law, Vol. 1, pp. 240-242. 
bring together these two systems of thought and separate doctrine. ${ }^{13}$ It was therefore not only inevitable that the notion of the trust fitted awkwardly with the common law concepts I have mentioned, but that judges trained on the common law side, which was the home of commercial law, should be hesitant to give it full rein when its potential for upsetting the structure and operation of the common law concepts was so considerable.

\section{LAW AND EQUITY: DOCTRINAL INTERRELATION}

The trust was a complete stranger to common law thinking, and this can be seen by looking at the section on 'Trust and Related Concepts' in any text on the law of trusts or of personal property. The points of contrast and of similarity are essentially academic; the texts rarely say anything about the respective practical functions of the trust and the particular common law concept. The trust, let us remind ourselves, is an obligation arising out of a fiduciary relationship with regard to specific property; the party with title to property must hold it, or, as the case may be, administer it for another. He must act honestly and carefully, and Equity requires him to account. Having created the duty of the fiduciary to account to the beneficiary, Equity saw the beneficiary as having his own interest in the performance of the fiduciary duty, and hence in the property being held or administered. If the fiduciary broke his fiduciary duty, Equity thereupon permitted the beneficiary to invoke the equitable tracing remedy, that is, to recover the property in question from the third party who took for value with notice of a breach of trust, or took gratuitously. Equity considered that, faced with a fraudulent or mistaken trustee who had wrongly parted with the fiduciary property, the beneficiary of that relationship had a better right to the property than anyone except a purchaser of the legal title for value and in good faith. In other words, Equity's considerations are two-fold: (1) fiduciary relationship and specific property, and (2) the relative equities of wronged claimants to the property in dispute. Whenever the first of those two considerations exists, a trust will arise, and bring with it the second in a tracing action.

Consider now the common law concepts. These are based on two different elements, that is to say, personal obligation between two persons arising out of agreement or delict, and the concept of possession. Contract gives rise solely to in personam obligations. However, the promisor's right is a chose in action, and that is a form of property; if they choose, promisor and promisee can intentionally make the promisee a fiduciary, a trustee of his chose in action for a third party. Agency, which need not but usually does arise out of contract, requires the agent to act as instructed, even to the extent that his instructions may be changed.

13. In the Canadian provinces the unified court system was either introduced (e.g., Ontario) shortly after the 1873 legislation in England and Wales, where a unified system had not existed from the beginning of the particular province, and in the western provinces, given their late date of founding, the latter situation was uniformly the situation. For a close study of the situation in Alberta, see J.E. Cote, 'The Introduction of English Law into Alberta', (1964) 3 Alta L. Rev. 262, esp. at 276-278. 
The rights and duties are in personam, between the principal and the agent. He may have title to the principal's property for the purposes of the agency, but usually the agent has sole possession, or the mere capacity to transfer title from the principal to the third party. If he has title, however, he is also a constructive trustee. In the U.S.A. he is described as an "agent-trustee". ${ }^{14}$ That is to say, he holds the title as a fiduciary for the principal, but otherwise is subject to his common law duty to carry out his principal's continuing instructions. Of course, if he has possession only, and no authorisation to pass title to a third party, the common law regards him as incapable of passing title, unless his wrongful act falls within one of the exceptional situations to the common law rule that no mere possessor, any more than a thief, can pass title. And with possession only, you will recognise, he cannot be a trustee to the property in question.

Possession is also the hallmark of bailment; the bailee of goods, such as the consignee for the purpose of sale to third parties, has possession for a declared purpose. He cannot also be a trustee, because he does not have title to the goods. However, if Equity's fiduciary accounting remedy or its tracing remedy is in the circumstances superior, it is not difficult to see why some recent courts have been prepared to characterize the wrongful possessor as a constructive trustee..$^{15}$ The common law remedy of detinue is inapplicable if the acquisition, as well as the retention, of physical possession is wrongful. And, even had the wrongful possessor been a legal possessor, the common law remedy of conversion would still have been inadequate, because the owner's entitlement is to damages only, and what he can obtain by a 'following' at law.

Then there is debt. Like agency, debt need not arise from contract, though except in an estate planning context it usually does. But whether or not it does so, the debtor and the creditor are related to each other by personal obligation only. Unless the creditor has security over specific property of the debtor, either by way of an arrangement between the parties, or registration of a judgment debt, he has only an in personam action against the debtor. He sues for an equivalent amount to the sum he lent, plus such interest, if any, as was agreed. This means, of course, that if a principal transfers monies to his agent for the purposes of the agency, or the agent receives monies from a third party, and the agent has to pay over an equivalent sum, the principal is a creditor and the agent his debtor. However, if the agent is required by the principal to keep those monies in a separate account, Equity regards the monies as earmarked, and the agent a fiduciary of the account for the principal. The principal may now choose to pursue his remedy at law for an equivalent sum, or he may require the agent to hand over the monies represented by the separate account. If the principal claims the latter, he claims as the beneficiary of a constructive trust.

14. See Scott on Trusts, 3d., para. 8 (esp. at p. 79).

15. Eg., Goodbodyv. Bank of Montreal (1975) 4 O.R. (2d) 147, 47 D.L.R. (3d) 335. 
Whether the parties intended a trust rather than debt relationship, or the holder of monies can be characterized as a constructive trustee for another, regardless of whether they intended a trust, depends in most cases on the arrangements they made. ${ }^{16}$ Of course, if the parties expressly said that the recipient of the monies is to hold them as a trustee for the supplier, that concludes the matter. But even the creation of an express trust does not mean that the transaction cannot also be a loan. If $A$ lends money to $\mathbf{B}$ for expenditure on a specific purpose, and requires that $B$ keep the monies meanwhile in a separate bank account, $B$ is a trustee of those monies for $A$ until they are drawn out and expended upon the specific purpose. At that moment of expenditure B becomes solely a debtor towards A. ${ }^{17}$ Indeed, at common law he would have been a debtor from the beginning; this state of affairs is merely masked during the first phase of the arrangement by the co-existing trust.

The holder of monies will also be characterized as a constructive trustee, however, when, though they have not used the language of trusts or even expressly thought in those terms, the parties have in fact agreed that the debtor shall hold the monies in a separate account and use them for a specific purpose. For instance, if, instructed by its parent company, bank $A$ lends one million dollars to bank $B$, in order that $B$ may loan that amount to $C$, and $A$ requires that $C$ 's repayments to $B$ shall be put into the same separate account at bank $B$, which was opened to receive the original one million dollars, $\mathrm{B}$ is a constructive trustee as well as a debtor vis-à-vis A. ${ }^{18}$

These distinctions between the trust and common law concepts are of crucial significance when the recipient of goods or money, either from the other party to a contract, or from a third person for that other party, becomes insolvent or bankrupt. It will also be crucial when one party, now insolvent or bankrupt, has earlier promised for value to hold the title to certain property, already in his name, for another. Whether there is insolvency or bankruptcy, property held by the insolvent or bankrupt in trust for another is not available for creditors; it is not the property of the insolvent or bankrupt, and therefore must be handed over to the trust beneficiary, or a new trustee for that beneficiary. Section 47(a) of the Bankruptcy Act, ${ }^{19}$ stating that property held in trust by the bankrupt is not subject to the bankruptcy distribution, represents a principle which

16. Eg., the bankrupt real estate listing agent does not hold the commission, payable out of the purchase monies, on trust for the selling agent. It is a matter of agreement and debt, because there is no intention to create a trust. See, for instance, Re Century 21 Brenmore Real Estate Ltd. (1980) 28 O.R. (2d) 653, 111 D.L.R. (3d) 280 (C.A.). Nor was there any special character to the relationship between the two agents, or any unjust enrichment justifying a constructive trust. There was simply a written agreement or understanding in the trade that one should look to the other for payment of monies due as the claimant's share. See also for the necessity of intent when there is no unjust enrichment, Re Ontario Worldair Ltd. (1983) C.B.R. (NS.) 116 (Ont.).

17. Barclays Bank Ltd. v. Quistclose Investments Ltd. [1970] A.C. 567, [1968] 3 All E. R. 651 (H.L.), cited with approval by Huband J.A. in Re Winnipeg Mortgage Exchange Ltd., supra n. 2 (C.B.R.) at 144-145. For an earlier authority, see Re Nanwa Gold Mines Ltd. [1955] I W.L.R. 1080, [1955] 3 All E.R. 219.

18. Mercantile Bank and Trust Co.v. Credit Europeen S.A. (1980) 32 N.B.R. (2d) 239 (Q.B.), 9 E.T.R. 195, upheld on appeal, (1982) 36 N.B.R. (2d) 339, 10 E.T.R. 165 (N.B.C.A.). 
can be traced as far back as the early eighteenth century. Indeed, the principle is the cornerstone of the English law of trusts, fundamental in all common law jurisdictions. ${ }^{20}$

So you may well say at this point, 'What an extraordinary situation! This 'trust' can come into existence, not only when a settlor or testator expressly creates it (which one can understand), but whenever specific property is being held or administered by one person for another. Moreover, when that happens - and such holding or administration can happen despite the co-existence of agency, debt, or even, it seems, mere factual possession by a wrongdoer - the beneficiary of that fiduciary relationship has an unassailable right in the circumstances of insolvency or bankruptcy to take ahead of all unsecured creditors, and to trace the property he so claims even into a mixed banking account, a remedy unavailable at common law'.

Potentially at least it is indeed an extraordinary situation, though to the best of my knowledge its ramifications for commercial law have not been explored. ${ }^{21}$ Few appear to be aware of the inroads the trust has made into commercial matters, and no one knows at present how pervasive the new constructive trust will be, based as it now is in Canada upon the foundations of unjust enrichment.

\section{THE USE OF THE TRUST IN PRACTICE}

This evening I would like to pursue three aspects of the subject of trusts in the area of bankruptcy, and suggest to you both the nature of the problems we are facing, and possible lines of solution. The first concerns documentation in the mortgage broking business, the second the trust and security arrangements in commercial wholesale financing, and the third the doctrine of tracing in the area of secured transactions.

\section{A. TRUST OR DEBT?: THE FINANCIAL INSTITUTIONS}

Of the four financial institutions in Canada - the banks, trust companies, insurance companies, and the loan and mortgage companies only the trust companies are empowered to offer trustee services to the general public. ${ }^{22} \mathrm{~A}$ bank that wishes to create an investment trust for public subscription, therefore, needs the services of a trust company. ${ }^{23}$

19. R.S.C. 1970, c. B-3.

20. This is the most difficult doctrinal point for civilians of the Roman tradition to accept when asked to recognise the common law trust, and yet, if they refuse to recognise it, they inevitably fail to recognise the trust.

21. Two valuable articles have been written by a commercial lawyer on the English law doctrine of tracing, however. See R.M. Goode, "The Right to Trace and its Impact in Commercial Transactions', (1976) 92 L.Q.R. 360 and 528.

22. This is provided in the federal Trust Companies Act, R.S.C. 1970, c. T-16, and counterpart provincial trust company legislation.

23. Banks and Banking Law Revision Act, S.C. 1980 , c. 40, s. $174(1)$ and (2)(b). The distinction between trusteeship on the one hand, and administration "for a trust" on the other, appears to refer to trusteeship, and agency on behalf of a trust. See s. 173(1)(o), bank empowered to "act as an adviser and consultant to, and an administrator for, a real estate investment trust." 
The bank will sponsor the trust and provide initial financing, but the trusteeship must be placed in the hands of a trust company, whether or not especially incorporated for the purpose, which, however close it is to the bank through the membership of its board, is capacitated to make independent trustee decisions on behalf of the investing beneficiaries.

Trust companies aside, the other financial institutions contract as debtors with the public. Simply expressed, banks borrow in return for services and interest payments, and are themselves lenders; ${ }^{24}$ insurance companies will sell coverage against future events, and themselves off-set invest. Loan and mortgage companies contract to lend, against security, in return for installment payments of returned capital plus interest. But the statutory exclusivity given to trust companies over trusteeship does not, of course, prevent any institution from becoming a constructive trustee. For instance, if a bank account records monies as owing to an account holder who is in fact a fiduciary over that account in favour of another, and the bank either knew or ought to have known of this fiduciary status, it becomes liable as a trustee de son tort if it knew or ought to have known of the breach by that fiduciary, and yet carried on as if the fiduciary had no such obligation. ${ }^{25}$ Moreover, having knowledge of the fiduciary status, it has no right to set of $f$ the monies in that account against an overdraft otherwise owed by that account holder to the bank. Knowledge has made the bank itself a fiduciary, a constructive trustee.

Then again, though trust companies alone are authorised to carry on business as a trustee, this does not mean that no other company can expressly assume the role of trustee. Unless it is denied the right by statute of the incorporating or licensing jurisdiction (and I know of no jurisdiction which does this), a company can legitimately hold property on trust if that is merely incidental to the carrying out of its objects. ${ }^{26}$ As Feehan $\mathrm{J}$. said in the Parkland Mortgage Corporation case, it would have a "devastating impact" on the operation of companies, and "necessitate a sweeping change in the way companies do business", if that were not the law. ${ }^{27}$ Nor are trust companies restricted to trust business. They are

24. Though a new concept of lending ("deposit arrangement") is introduced by the Banks and Banking Law Revision Act, supra, Schedules, Pt. V, ss. 96-99, in order to permit the chartered banks to offer to the public R.R.S.P.s and R.H.O.S.P.S, the bank as "depositary" of money for a plan "beneficiary" has no power to discharge other debts ow. ed by the beneficiary to the bank out of that money, and the beneficiary may not pledge, assign, or otherwise encumber the fund. For the purposes of the Canada Deposit Insurance Corp. Act, R.S.C. 1970 , c. C-3, as amended, such a deposit must be kept separate by the bank from any other deposit of the individual concerned (see id., s. 93).

25. Groves-Raffin Construction Ltd. v. Canadian Imperial Bank of Commerce [1976]2 W.W.R. 673, (1976) 64 D.L.R. (3d) 78 (B.C.C.A.). Bankers are naturally concerned at this demanding level of liability. Constructive knowledge, which would be the usual basis of liability, implies negligence on the part of the bank, and it is a nice question whether a banker as a mere debtor should be liable on this basis. Actual knowledge is surely a more reasonable and sufficient requirement; but see the Banks and Banking Law Revision Act, supra n. 23, s. 206(2). There is a strange contrast here with the Torrens land title registration system where we are prepared to protect the register to the point that the registered title holder is not bound by a previous unregistered title holder, of whom he actually knew.

26. Parkland Mortgage Corp. Ltd. v. Therevan Development Corp. Ltd. [1982] 1 W.W.R. 587, 130 D.L.R. (3d) 682 (Alta.)

27. Id. at 691 . 
authorised by statute not only to carry on the business of trusteeship, but to receive deposits by the public for the purpose of investment and an interest return. In this latter sense the trust company contracts as a debtor, the guaranteed investment certificate being a ready example of such an investment. ${ }^{28}$

In these circumstances it is not difficult to see how important it is that persons doing business understand clearly whether they are creating a trust or a mere debt. No particular language is required in order for the parties to create a trust, as Barclays Bank Ltd. v. Quistclose Investments $L t d .{ }^{29}$ demonstrated; it is purely a matter of intent, and such intent is discoverable, as we have seen, in the contractual requirement that the monies received be kept separate by the recipient and be applied for a specified purpose. Trustees holding a trust fund will normally be required to invest that fund for gain, and a depositor who simply hands over his money for investment also looks for gain, usually at an agreed rate of return. In the event of the bankruptcy of the recipient of the monies, it will probably be crucial whether a trust or a debt was intended by the contracting parties, for the trust beneficiary will go ahead of all unsecured creditors. And this is where a problem starts. The Crown Trust affair, ${ }^{30}$ and the press comment it generated, have revealed how many members of the public do not understand what status they have as depositors, and one is compelled to ask whether as a society, both federally and provincially, we are doing enough to ensure that the public is informed when it parts with its money for investment.

Could we not require, at least, that the documentation employed by the institutions engaged in investing the public's funds makes it absolutely clear on what basis such institutions are taking in those funds?

28. As to the evidence which would determine whether the trust company is contracting as a debtor, or assuming the role of trustee, see McMahon v. Can. Permanent Trust Co. (1980) 6 E.T.R. 43 at 46 (B.C.C.A.).

29. Supran. 17.

30. In 1982, as a result of a highly publicised large-scale real estate transaction in Toronto, considerable public concern arose about the continuing financial viability of three trust companies, including the Crown Trust Co., whose assets had been committed by way of mortgage in that transaction. The Ontario government took the extraordinary step, under provincial legislation, of taking over the administration of these companies. Under the authority of the legislation the province stopped all business of the companies, while provincial officials examined the records, assets and transactions of the companies. Ultimately, Crown Trust Co., which had branches in several provinces, was compulsorily put under an agency agreement with another trust company, and this arrangement carried the guarantee that all obligations of Crown Trust $\mathrm{Co}$. would be honoured.

The distinctions in the trust company legislation (eg., Trust Companies Act, .R.S.C. 1970, c. T-16, ss. 2, 63 and 64) between the trusts set up by others, of which the company is trustee, and monies accepted from depositors for investment ("guaranteed trust money" evidenced by a "guaranteed investment certificate", and "unguaranteed trust money"), hardly assist the public's enlightenment. See now the Banks and Banking Law Revision Act, supra n. 23., s. 270, for a new trust. 


\section{DOCUMENTATION IN MORTGAGE BROKING}

Trusts appear now to be widely employed by mortgage brokers, and with reference to the clarity of documentation it is to this type of investment that I would particularly draw your attention . Investment in selected mortgages of land is a popular type of investment for those members of the public who are looking for a higher rate of return than they could obtain from the banks and trust companies. Many, perhaps most, investors realise that there is a greater level of risk in this form of investment, and such a person will carefully consider any specific mortgage offered to him by the broker before he advances his monies; once assigned a mortgage he will want to be assured his interest is registered on title (I am thinking particularly of the title registration jurisdictions), and he will keep a watchful eye on the regularity of the mortgagor's payments. He is concerned to monitor as far as possible the quality and security of his investment. But there are many who do not do this; they do not check closely or monitor the particular mortgage or mortgages in which they are invested, and they accept documentation from the broker which is somewhat less than explicit, because they are essentially relying upon the reputation and integrity of the broker. In recent months there have been two reported cases ${ }^{31}$ where just this kind of situation appears to have existed, and in both the trust was involved. When I discuss these cases, you will quickly realise what degree of reliance the investing public placed in each mortgage broker rather than the documentation he supplied. However, I would like to draw your attention to two things: first, the difficulty the courts have in determining what is the nature of the trust created, and, if there is a trust, what constitutes the trust property; secondly, the effect created upon the title registration system, and otherwise upon third parties, by the discovery of a trust.

Both cases concern the common practice of 'syndicating' mortgages. In most instances, particularly where the broker is dealing with relatively small investors, the investor will not advance the whole value of an existing mortgage, taking an assignment of that mortgage which is then registered on title in his name. He will have a sum for investment, and the broker will transfer to that person a part interest in a mortgage of larger value. In the result a group or 'syndicate' of investors is brought together, and each has a security interest in the one mortgage. Sometimes the broker will have mortgages which he has previously acquired, with his own or borrowed resources, and which he now transfers in each instance to an assembled group of investors; sometimes, especially when the intended loan is large, the broker seeks out investors for the would-be borrower, and their assembled funds are then advanced to the borrower against the security of the single mortgage. In the former situation the investor's monies are likely to be transferred to the broker who will then in due course notify the investor of the mortgage to which the funds have been allocated (the investor then having the opportunity to accept or reject that particular security). In the latter situation the investor's monies will probably be transferred to the broker when the necessary group of

31. I.e., Parkland Mortgage Corp. Ltd. v. Therevan Development Corp. Ltd., supra note 26, and Re Winnipeg Mortgage Exchange Ltd. and Winnipeg Mortgage Holdings Ltd., supra n.2. 
investors has been put together for the purposes of the particular mortgage. Of course, there may be variants of practice from broker to broker, but, generally speaking, this is how the system works. ${ }^{32}$

In Parkland Mortgage Co. v. Therevan Development Co., ${ }^{33}$ an Alberta case before Feehan J., eight investors advanced their monies to the plaintiff company for loan to the defendant company against the security of a mortgage of the defendant's property. It was clear from the evidence that the investors were attracted by the interest profit they would earn, and the plaintiff by the earning of a placement fee, paid by the defendant. These are the usual expectations. But what did it mean for the investors when the plaintiff proceeded to register the mortgage in its own name? What sort of interest did each investor obtain in the mortgage? It appears from the report, astounding as this may seem, that no documentation was originated by the plaintiff which would confer any interest upon any investor. It was left to the initiating correspondence between the plaintiff and the investors to show that each investor understood he would "own a beneficial undivided interest in the Therevan mortgage", and the trial judge concluded that a trust relationship "of some sort" had been created between the plaintiff and the investors. This, he thought, was the intention of the investors, and the plaintiff appeared to have recognised that they had such interest. But it was certain that nothing of the investors' interest appeared on title. ${ }^{34}$

If this, then, was the manner in which the investors received their several interests in the mortgage, the question shifts to this - what was the effect of that trust? First, it is important that we see what interests in the mortgage were later acquired by others. A bank made a loan to the plaintiff on the security of the mortgage, ${ }^{35}$ which the bank had found in the register clear of encumbrances, and subsequently two judgment creditors separately registered their claims against the plaintiff. Despite this, in a dispute between the investors and the judgment creditors as to who was entitled to priority, the investors succeeded and on a very simple basis - the plaintiff had no beneficial interest in the mortgage, or therefore in the monies in court which represented the defendant's repayment of its mortgage debt. As a result the judgment creditors had no entitlement to any part of that money.

It follows that had it not earlier been paid off by the plaintiff, the bank, too, would have been in the same position. When paid off, it was in fact an unsecured creditor. Though this was not an issue in the litigation, it is a conclusion to which one must inevitably come, once it is clear that the registered property owner was in law a trustee of that property.

32. A description of syndication, and the use of a trust instrument in a specific instance is given in $\operatorname{Re}$ Urman (1981) 38 C.B.R. (N.S.) 261, 272-274, 128 D.L.R. (3d) 33, 44-46 (Ont.).

33. Supran. 26.

34. Subsequently, after there came to light an attempted fraudulent dealing with the mortgage by one of the plaintiff's of ficers, a solicitor for some of the investors entered a caveat on title, but in circumstances which are not apparent this was discharged only six months later. It was not on title when any of the other claimants against the mortgage registered their interests.

35. The duplicate mortgage was deposited with the bank. 
Had it not been a trustee when it took the bank loan or became subject to the judgment registrations - a trust beneficiary can acquire no interest in property, to which the trustee has no entitlement - the plaintiff could have given an effective security interest to the bank or to each of the judgment creditors. But Parkland Mortgage Corporation never had a personal interest in the mortgage, or so it seems from the report. It certainly had no interest when the bank's mortgage was purportedly created, or the creditors registered their judgment debts. The effect of the trust, in other words, was that conceptually the trust beneficiaries, whether or not their interests were caveated on title, had to prevail. And they did.

In Re Winnipeg Mortgage Exchange Co. Ltd. ${ }^{36}$ the story is taken a stage further. The Parkland case shows there can be difficulty in determining whether a trust was intended, as we have seen, but it also reveals some doubts as to what was the trust property. The trial judge said the settlors were the investors; Parkland, he infers, admitted in the correspondence that it was a trustee for them. Had the trust because of the trustee's incapacity been invalid, said the trial judge, Parkland would have held the trust property on resulting trust for the investors. ${ }^{37}$ But, if the trust property was the mortgage, as the trial judge says it was, ${ }^{38}$ the investors could only be entitled to a resulting trust of the mortgage. Yet the learned judge also says that, had the trust been ultra vires of Parkland, the investors could have got their monies back, because through the resulting trust "they remain the beneficial owners of the subject-matter of the [invalid] express trust". ${ }^{39}$

Inevitably we are left with the question, did the investors loan their money to Parkland, and Parkland by agreement then settle the mortgage on the investors? The answer seems to be, no, because the judge decided the investors were the settlors. So we ask - did the investors, then, transfer their monies in trust to Parkland, agreeing that the trustee might substitute the mortgage for those monies? The trial judge appears to have concluded that this was the answer. But is that a correct analysis? Is it right that when the investor pays his money to the broker, the investor transfers his monies as a settlor of a trust, constituting the mortgage broker a trustee with a power of investment? Re Winnipeg Mortgage EXchange Co. quite clearly rejects that thesis.

As to the effect of the situation where the security asset allocated to the investor is held on trust for him, the Winnipeg Mortgage case reveals a profound difference of opinion at the appellate level as to what should be the position of the secured creditor who can point to his security among the assets in the bankrupt mortgage broker's hands, and the secured creditors who cannot. The majority opinion is a trail blazer; the question now is whether future courts will accept its revolutionary position.

36. Supran. 2.

37. Supra n. 26 at 693-695 (D.L.R.).

38. Id. at 695 and 697.

39. Id. at 697. 
The documentation in this case, unlike Parkland, certainly existed; indeed it reached horrendous levels of legal complexity, to the point that on the receivership and then the bankruptcy of the mortgage broker there were two trial actions arising out of the documentation, both of which went to the provincial Court of Appeal. ${ }^{40}$ The story really begins, however, when Winnipeg Mortgage Exchange Co., a well-known mortgage broking company in that city, closed its doors in the summer of 1979 , insolvent. At once a demonstrating crowd of small investors appeared on the steps of the provincial legislature, frightened for their savings, angry at everyone, and demanding that government make good any losses. A receiver was appointed, and it then became apparent how the two principal executives of the company had been conducting investments. At first, commencing in the late 1950s, the company had operated in the normal manner of charging the mortgage vendor a commission on the finding of a purchaser for him; later it purchased mortgages at a discount reselling them at or close to the face value. But then in the first half of the 1970s it changed significantly the manner in which it took its profit. It was, no doubt, already 'syndicating' mortgages, but now it resold mortgages or portions of mortgages, retaining for itself an interest differential. For instance, the company purchased a mortgage with a sixteen percent rate of interest, but sold at a twelve percent interest rate. This necessitated the company retaining the underlying mortgage; it sold (or purported to sell) a portion of that mortgage, but paid to the investor the lower interest rate. Then, in the later 1970s, during its last years, the company added another modus of providing for the investor his mortgage security. It continued to issue documentation purporting to sell, but followed it up with further documentation suggesting in effect that the investor was making a loan to the company on the security of a mortgage of a mortgage, the latter owned and retained by itself, or a portion of such a mortgage, as the size of the loan might require. In other words, what began as a mortgage vending business culminated in transactions of a loan and security character. ${ }^{41}$

However, in the last two stages, when Winnipeg Mortgage Exchange Co. was retaining the underlying mortgages, a so-called "trust agreement" was issued by the company to each investor, and the effective question was what it was by way of security that these "agreements" gave the investor. The matter was of crucial importance because, while after insolvency occurred most investors could not discover the specific

40. First action: Re Winnipeg Mortgage Exchange Ltd. (1980) 6 E.T.R. 225, 34 C.B.R. (N.S.) 289; rev'd (1980-81) 7 E.T.R. 225, 36 C.B.R. (N.S.) 78, 113 D.L.R. (3d) 257 (C.A.). Second action: Re Winnipeg Mortgage Exchange Ltd. and Winnipeg Mortgage Holdings Ltd., sub. nom. Ranjoy Sales \& Leasing Ltd. v. Down [1982] 4 W.W.R. 16, 41 C.B.R. (N.S.) 230; rev'd [1983] 1 W.W.R. 213,43 C.B.R. (N.S.) 119 (Man. C.A.).

41. I have followed here the analysis of Huband J.A. in the second case at the appellate level. Supra n. 40. 
underlying mortgages once allocated to them, or purportedly allocated to them, a number of investors could do so. ${ }^{42}$ And the cause of this state of affairs is revealing. Beginning with the early days of the business, investors essentially relied on the integrity of the company, and the promise that, come what may, the company would see that the promised interest was paid for the contracted term. Investors either made no investigation of mortgages purportedly allocated to them and asked nothing about the documentation, or they made but desultory enquiries and blandly accepted the explanations they were given. In retrospect it can be seen as a prescription for disaster; clients knew nothing and asked for nothing except their promised regular interest payments. Behind the company's doors, however, mortgages were being handled like a business inventory - bought and sold, foreclosed or maintained though in arrears and this was increasingly done without reference to the clients' allocated mortgage interests. Meanwhile, interest payments to clients were made out of the general company account, into which all receipts went, and out of which all company outgoings were paid.

So it was that, when the end came, the fortunate few sought to realise on their discovered security, while the unfortunate many resisted this as grossly unfair. But there was also the legal question - what security, if any, did the documentation (a mortgage purchase contract, a mortgage allocation letter, and the "trust agreement") give any investor?

The mortgage purchase contract, and the allocation letter, did not essentially change throughout the $1970 \mathrm{~s} .{ }^{43}$ The first showed the amount invested, the interest to be paid, the dates and duration of interest payments, and a "designation" of a mortgage security; the investor agreed to purchase a mortgage, and appointed the company his nominee to administer the mortgagee's rights and powers. The second, the allocation letter, was a communication from the company to the investor, informing him that, in completion of the purchase, a described mortgage had now been "allocated" to him. These descriptions, however, ranged from a degree of land title registration detail to a vague street name reference.

The third document was the "trust agreement". This was the document which changed subtly during the decade, the investor obtaining the form of the "agreement" which was current at the time he made his investment. Some four or five versions were ultimately before the courts, but they were essentially of two kinds. In the first the company acknowledged the sale of a portion of the particular mortgage, declared that it held and stood possessed of the said mortgage (or part of the said

42. During the 1970 s residential residences became hard for the company to obtain, and later it purchased from its agent mortgages on commercial properties. The commercial mortgages were not only more speculative in nature, but when the market turned against the company, and foreclosures were more than it could cover from its profit margin, the two principals operating the company turned to devices which continued the policy of telling investors nothing, but which resulted in the continued payment from a general cash account of the interest promised, while the real underlying mortgages were either disappearing, fictional mortgages taking their place, or being dealt with on the market in totally improper ways. When the collapse came, only part of the true portfolio was still in place.

43. [1982] 4 W.W.R. 16 at 46 (7th para.), 41 C.B.R. (N.S.) 230 at 257 (8th para.), per Wright J. in the second action at trial level. 
mortgage $)^{44}$ as trustee for the named investor, and declared also that it would remit to the investor the agreed portion of all monies received by it pursuant to the mortgage. In the second the company declared that it had mortgaged the said mortgage (or part of the said mortgage) to the named investor, that it held and stood possessed of the said mortgage (or part of it) as trustee for the investor, and that it would remit the mortgage payment (the interest) (or "part of all monies received") to the said "purchaser"' (or the named investor).

It was the effect of these "trust agreements" that divided the courts before which they came. And all of them, it should be noted, involved syndicated mortgage transactions, where a part of a mortgage had been purportedly sold or mortgaged. In the first court action, when the receiver sought advice and directions, ${ }^{45}$ Wright $\mathrm{J}$. at first instance thought that there was an express trust as soon as the investor handed over his money, and that this trust of money ultimately became a trust of an interest in a mortgage. However, he considered that the express trust beneficiary had to be able to point to the particular mortgage among the company's assets before he could allege there was such a trust. So far as the investors were concerned who could not so point to their mortgages, he was of the opinion that a constructive trust arose in favour of those investors over all the remaining mortgage assets. It was unconscionable that the company should have these assets; unconscionable, presumably, that the company's trade creditors should share in them. The Court of Appeal disagreed. ${ }^{46}$ For the Court O'Sullivan J.A. thought that, as to the mortgage of a mortgage, there might be a trust of the document creating a mortgage of a mortgage, but that it was by no means clear. The trust could not be of the underlying mortgage itself, because the company had retained part of the interest due under that mortgage, and nothing was said of this in the "trust agreement". When on the other hand there was a sale and an assignment of a mortgage (or part of a mortgage), it was possible that there was a trust of the agency duty of the company to collect the mortgagor's payments, or part of those payments, for the investor. ${ }^{47}$ However, the Court considered that the receiver should file an assignment in bankruptcy because litigation was inappropriate under provincial law procedures, and so the matter of the trusts was left there.

The second action, ${ }^{48}$ brought against the trustee in bankruptcy by the investors who could point to their securities, raised the same issue. This time Wright $\mathbf{J}$. at first instance abandoned his earlier view that there was an initial trust of the investors' monies, and he distinguished between the instances of sale and of mortgage. As to the sales, he held there was an express trust, and also a constructive trust, of the mortgage (or the part

44. Sometimes an "agreement" referred to a "part of the said mortgage", but all investors who obtained either this document or the one referring to "the said mortgage" were ob. taining an interest in only a part of the mortgage.

45. Supra n. 40.

46. Id..

47. Of course, since the agent would be a fiduciary in these circumstances, there would also be a constructive trust of collected payments. Possibly O'Sullivan J.A. intended to refer to a constructive trust, and was not thinking of an express trust.

48. Supra n. 40. 
of it). The constructive trust arose out of there being a binding contract of sale. In the case of a mortgage of the underlying mortgage, he concluded that when the instrument said the trustee "holds and stands possessed of the said mortgage", the trust must include the underlying mortgage also. Only in the instance where the trust instrument purported to create a trust of "part of the said Mortgage of Mortgage" did failure ensue. The part was not identified, he said, nor could a trust be created over an equitable interest of that kind. He meant presumably that the description of the subject-matter (or property) of the trust was too vague.

Again the Court of Appeal disagreed. ${ }^{49}$ Huband J.A. thought that, while there was an express trust in the sale cases, all the trusts of mortgages of mortgages failed, not just those that referred to a part of a mortgage of a mortgage. His basis for this was simple: when Exchange declared itself a trustee of a mortgage of a mortgage, the underlying mortgage was never part of the trust property. This is to say, as trustee Exchange had no right to sue the underlying mortgagor for the interest payments that he owed. Exchange, as mortgagee, retained that right in itself. Presumably, as O'Sullivan J.A. had earlier suggested, Huband J.A. saw the mortgage of a mortgage as merely the mortgage of a mortgage document. ${ }^{50}$

Now for the surprise. Freedman C.J. had already intimated after the hearing that, if a way could be found in which all the investors would share in the losses proportionately to their original investments, he would take that route. And so he did, Monnan J.A. concurring with him. The Exchange company officials, he said, had from the beginnning intended to treat all investors equally; that was the governing factor. All investors would be treated by the Court as if they were unsecured. The Chief Justice's judgment was as simple as that. 'Equality is Equity', as a Chancery lawyer might have put it. However, this was an argument which at first instance Wright J. had dismissed in three lines - "There is no legal basis for the application of that idea here", he said" his part Huband J.A. confessed his "absolute astonishment" 52 that his brothers, the majority, would draw no distinction between trusts of mortgages and trusts of mortgages of mortgages. The first was a purchase coupled with an effective trust, he said, the second a loan coupled with an inef fective trust.

49. Id..

50. Moreover, as he very rightly pointed out, a trust of a mortgage of a mortgage cannot itself be the instrument of creation of the mortgage of a mortgage that is to be held on trust. There was no registrable mortgage of a mortgage in existence at any time. There was only an equitable right to one. Incidentally, Wright $\mathrm{J}$. at first instance concluded that an equitable right to a mortgage of a mortgage is a mortgage of a mortgage, and the creation of the trust created that right also, which Exchange then held for the investor. The Court of Appeal did not comment on this reasoning, though a persuasive argument can be made for it.

51. 41 C.B.R. (N.S.) 230 at 268.

52. 43 C.B.R. (N.S.) 119 at 151 . 
But it was all over. An appellate judgment that came out of the blue, and had all the ring of a Denning decision, had prevailed. And who can say at the end of the day that justice had not been done? In a shipwreck of this nature should anyone have been able to claim a reserved seat in the only lifeboat that had not capsized? There is of course a counter argument, it is a powerful one, and much will probably be heard of it in the future, ${ }^{53}$ but for our purposes this evening the Winnipeg Mortgage Exchange case tells its own tale. The so-called "trust agreements" were in fact declarations of trust, some of the trusts were created over assets that may not have existed, and trusts were utilised in sale and pure loan situations without apparent understanding by the company officers of the distinction. Indeed, it is difficult to believe that those officers, one of whom was a lawyer, really knew much at all about the trust. In the courts, for their part, there were differences of opinion about when the trust arose, whether the constructive trust came into the picture as well as express trusts, and what a trust of a mortgage of a mortgage means or involves.

\section{B. TRUST DOCUMENTATION WITH RESPECT TO LAND}

I am not able to hold out to you that the confusions which existed in the thinking of the Winnipeg Mortgage Co. of ficers were singular to that company. If they were, and if there were not reason for a general concern, the Winnipeg Exchange case would hardly justify the attention I have given it. But in fact my enquiries suggest there could be a pervasive problem here. The conduct of the Parkland Mortgage Corporation, and the failure in my view of the Alberta Torrens system to provide adequately for the recording of trusts on title, ${ }^{54}$ can give little reassurance to investors, but be that as it may; it would be impertinent of me to point the finger at affairs in your own province. Let me instead turn to the situation in British Columbia, and leave you to ponder whether matters here also require further examination.

In the first place there is the problem of adequately informing the investors of the particular mortgage or mortgages in which they are invited to invest. In British Columbia since November, 1976, it has been incumbent upon the broker and anyone else who proposes to offer a syndicated mortgage to the public to file a prospectus under the Securities Act, ${ }^{55}$ so that, as with the policy in regard to any investment in securities covered by the Act, members of the public can know in advance who is making the offer, the terms of the mortgagor's obligations, the property which is to be the security for the loan, and the continuing responsibilities of the of fering broker or other offeror once members of the public have taken up the offer. If no prospectus is to be issued, an exempting order of the Superintendent of Brokers must be obtained permitting this omission, and such an order will be given only if certain conditions are met.

53. For an early comment, see (1983) 44 C.B.R. (N.S.) 166 (S.H. Wilder).

54. For an opinion along the same lines on the part of an author from another Torrens jurisdiction, see Robert Stein, 'Torrens Title - A Case for the Registration of Trusts in New South Wales', (1982) 9 Sydney L.R. 605.

S5. R.S.B.C. 1979 , c. 380, s. 36 . 
First, the investor's interest in the mortgage must be registered 'on title', or the interest must be held in trust for him by a trust company or a member in good standing of the provincial Law Society. This means that a broker cannot syndicate in fact, but keep the title to the mortgage in his own name on the register. Such a practice is potentially popular with brokers and their investing clients who would keep the costs of syndication, and assignment trading in part interests, at their lowest possible level. Secondly, there must be no guarantee of return on the investment. That is to say, the broker cannot guarantee, for instance, ten per cent per annum during the period of investment, even though the mortgagor defaults during that time. Thirdly, the rate of interest offered to the investor must be the same as that which is stated in the mortgage itself. This would mean, for instance, that the offeror cannot syndicate a twelve per cent mortgage at a rate of fourteen per cent in order to make it more attractive to investors when rates have generally risen. In any event there is no security for the extra two per cent. Nor may he syndicate the same mortgage at ten per cent, taking the margin himself as his profit. ${ }^{56}$

However, even if he is unaware of what pre-offer formalities have been followed by the broker or other offeror, the land registrar is likely to require that all the investors appear on the title, or alternatively that a solicitor hold the title as trustee for the investors. It is possible under our Land Titles $\mathrm{Act}^{57}$ for each part owner of a mortgage to appear on the certificate of title itself, lists of such owners in the register sometimes running to two or more pages. Alternatively, if a trust has been employed, the name of the title holder may appear on the certificate as trustee, and the names of the investors be listed in a schedule to the trust instrument. Since a copy of the trust instrument and its schedule will then be deposited with the title office, and a notification of the existence of the trust instrument will appear on title, the investor's security is equally well protected, so far as title is concerned. ${ }^{58}$ Should a part owner of the mortgage assign his interest (and provision is regularly made for this in the terms of the documentation), the assignee's name will take the place of the assignor's on the title ${ }^{59}$ or in the schedule, as the case may be.

56. See Notices dated November 12, 1976, and April 20, 1977, 'Re: Sale of Interest in Mortgages (Syndication)', CCH Canadian Securities Law, paras. 29-988 and 29-988a (pp.789729 and 30). These notices were probably issued in the light of Re Western Ontario Credit Corp. Ltd. and Ontario Securities Commission (1975) 9 O.R. (2d) 93, 59 D.L.R. (3d) 501 (Ont. Div. Ct.). There on appeal by the broker, the Divisional Court upheld the Commission's decision that the broker should cease trading in securities. The Commission had considered that 'trading in mortgages' ( see s. 20(2)(e) in the case of the Securities Act in British Columbia, supra) was not trading in securities within the Ontario Securities Act, but that a scheme, whereby the public was invited to invest at a guaranteed rate of interest with security in the form of a part interest in a mortgage which mortgage expressly might be changed by the broker during the investment period, did constitute trading in securities within the Act. The broker and the investor were entering into an investment contract, and this was trading in securities.

57. R.S.B.C. 1979 , c. 219 , s. 193.

58. Id., s. 176.

59. See id., s. 197, which requires a charge to be registered before recognition of the assignment on the register may take place. Registration thus gives the assignee the register's confirmation of the assignor's ownership. 
Whether all those promoting syndications of mortgages are properly following these required practices, especially those where the of feror contacts investors whom he knows to be interested in investing in this manner, and he keeps his enquiries to that small circle, can only be a matter for speculation. In some respects there could be debate as to whether the Commission's notices are intended to apply if the public at large is not involved. In $R e$ Western Ontario Credit Corp. and Ontario Securities Commission, ${ }^{60}$ where the Divisional Court held that the broker was indeed trading in securities, he was of fering syndicated mortgages not only to the public, but through promotional literature. On the other hand the language of the British Columbia notices is comprehensive enough to include all situations where the investor acquires a part interest only in a mortgage.

What particulary concerns us here, however, is the documentation which brokers and other offerors employ in British Columbia. It is usual for the transfer of interest to be structured as a unit trust. The mortgage value is divided into units, and the investor who buys a portion of the mortgage acquires an equivalent number of "units of ownership". The title holder is usually described throughout the document as an 'Agent'; he is presented as an agent of the unit holder, acting on the unit holder's behalf, though the document may also actually state that the unit holder's interest in the mortgage is held in trust for the unit holder by the 'Agent'. Since ownership is in the 'agent' who is in fact a trustee, and the investor has simply an equitable interest in the mortgage, it is difficult to resist the impression that such documents are more designed to instill confidence in the investor than simply and directly set out the legal position. Whether or not notice of the trust appears on title, there is the problem of what rights the trust beneficiary acquires in the mortgage, for that is the trust property. The mortgagee's rights against the mortgagor are indivisible, and this provides a major problem for all investors in syndicated mortgages. If the part owners are on title, and the mortgagor pays off one part owner, the registrar will not discharge a mortgage that is only a proportion of a whole. A modification agreement between all the part owners is necessary. ${ }^{61}$ If a trust is employed, and the investors are beneficiaries of that trust, the title to the mortgage and therefore the mortgagee's rights are vested solely in the trustee. What is the position, then, if the mortgagor defaults and the investors are of different minds as to whether the mortgage should be foreclosed? The trust instrument will state that each investor appoints the 'agent' to act on his behalf in the administration of the mortgage, but, as we have seen, in truth the so-called agent is a trustee; if the beneficiaries are divided as to how any right of the mortgagee should be exercised, the decision is made by the trustee, and he could be in breach of trust if he effectively delegates the matter to the beneficiaries by the counting of heads.

60. Supran. 56.

61. Quite properly, and apart from the possibilities of a fraudulent preference, the registrar takes the view that all the part owners must consent, because, following the payment of the one part owner, the interests of the unpaid part owners in the security and the debt have changed. In fact, the modification agreement terminates the existing mortgage, and creates a new one. 
Moreover, it is also possible for each investor in the one mortgage to have his own trust. That is to say, the title to the mortgage is in one person, and that person appears as the trustee in each trust for each investor who has as security a part (or percentage) of the mortgage. Of course, such an arrangement may make the investor feel he has his own captain on the bridge, making decisions that are best for himself as the one trust beneficiary. But it is no whit better an arrangement than the single trust. It cannot be. And the situation could be worse. The several trust documents could be differently worded, as in the Winnipeg Exchange case. If they are different, then all of them may be invalid, since it would not be clear which instrument the trustee is to follow in the exercise of his one indivisible set of rights.

Single trusts and multiple trusts present for the draftsman another problem, even before we get to the problem of the validity and efficacy of multiple trusts. Where he has originated a number of trust documents, has he clearly spelt out whether each document relates to a single trust or each document creates a separate trust? Trust lawyers know well how difficult it is to conceive of, let alone draft, a number of indentures which are to be construed as creating a single trust in favour of a number of beneficiaries. One shudders at the thought of the multitude of documents which may be in circulation, purporting to do one thing, but in all possibility achieving, if anything, something else.

When one looks at the whole business of syndicated mortgage broking in perspective, there is in my opinion a first level of reform which the law can fairly quickly adopt to alleviate these problems. Little can be done to protect the investor against himself when he decides to risk his money on a speculative investment, and he makes no adequate investigation of the soundness of the mortgage security offered to him. But surely we can provide that the documentation which he is asked to accept is intrinsically valid. It seems to me that the mortgage broker or any other offeror should only be allowed to proffer documentation which has been approved by the securities commission of the jurisdiction. In the cause célèbre of Winnipeg Mortgage Exchange Co., as well as in the Ontario case of Western Ontario Credit Corp., where the documentation used was remarkably similar, such a practice would have gone a long way to prevent irregularities. Trust documentation which may be used by brokers and others will have been examined as to inherent validity, and the form of such documents standardised, if my suggestion was adopted.

Moreover, I suggest with respect that our concern with syndicated mortgages should go further than policy notices from the provincial securities commission. In British Columbia, as it seems to me, the Securities Act should expressly deal with the unit trust, as well as all other methods of conferring upon the investor a part interest in a mortgage. Do such devices 'trade in securities', and, if so, when do they do so? Next, we should deal with the Mortgage Brokers Act ${ }^{62}$ by expressly dovetailing it with the Securities Act. Then there could be no debate as to which mortgage trading transactions are exempt from the Securities Act. There

62. R.S.B.C. 1979 , c. 283. 
would no longer be any 'walking [of] a very fine line', as the British Columbia Securites Commission describes the conduct of brokers who would plead the Mortgage Brokers Act as the defence for their not complying with the Securities Act.

\section{B. THE TRUST AND SECURITY ARRANGEMENTS IN COM- MERCE AND WHOLESALE FINANCING ${ }^{63}$ \\ 1. TRUST OTHER THAN IN WHOLESALE FINANCING}

It is clear that, if a lender loans money to a debtor for a specified purpose, and the lender requires that, until it is expended upon the purpose, the money is to be kept in a separate account, the debtor holds the money as a trustee for the lender. ${ }^{64}$ Nor need the words, 'trust' or 'on trust', be used in the documents setting up the loan; the courts can find from the particularisation of the purpose, and the requirement that the money be kept separate from other monies, that the lender, as settlor, intended to create a trust. ${ }^{65}$

The effect of such an arrangement as this, and no doubt its object, is that the lender is secured until the monies are expended upon the purpose. He claims either as an express trust beneficiary or a resulting trust beneficiary, but either way he obtains recovery of the entire sum lent, even though the insolvency or bankruptcy of the debtor intervenes. Should any part of the sum have been used by the debtor otherwise than for the specified purpose, the lender as a trust beneficiary may trace the monies in question, a remedy no unsecured creditor enjoys. And it is irrelevant that the debtor does not in fact keep the borrowed monies separate, either initially or at any later stage prior to the proposed expenditure, whether as to the whole or a part of the sum borrowed, provided that it is clear the lender advanced his monies by way of a trust for himself until the moment of authorised employment occurred.

The intention of the person advancing the monies has always been regarded as crucial. It is he who creates the trust; those are the terms of his advance. Indeed, were it possible for the person receiving the monies to declare a trust of them for the person advancing them, it would seem inevitable that such an act in circumstances of insolvency would constitute a fraudulent preference of creditors, and it is for this reason that Megarry V.-C.'s decision in Re Kayford Ltd. ${ }^{66}$ is so curious.

63. The classic article on the subject of wholesale financing in this country is by J.S. Ziegel, 'The Legal Problems of Wholesale Financing of Durable Goods in Canada', (1963) 41 Can. Bar Rev. 54.

64. The trust we are assuming in these circumstances is an express trust. The constructive trust will be imposed when no trust was intended, but an agent holds monies in a separate account for the principal, as agreed with the principal.

65. Barclays Bank Ltd. v. Quistclose Investments Ltd., supra n. 17 at 579-581 (A.C.). Followed in Steffanson v. Jaasma [1976] 4 W.W.R. 449 (B.C.S.C.), and applied Mercantile Bank and Trust Co.v. Credit Europeen S.A., supra n. 18.

66. [1975] 1 W.L.R. 279, [1975] 1 All E.R. 604. 
The managing director of a mail order business was apprehensive of the forthcoming bankruptcy of the business, and concerned that customers who remitted monies for the purchase of goods, which could not immediately be supplied, would be harmed by such bankruptcy. Consequently, he arranged that all customers' monies to be remitted in the future should be paid into a separate trust deposit account. The feared bankruptcy occurred, and the customers' monies were indeed held not to be the company's funds. The learned judge found an intention to create a trust in the discussions of the managing director with his accountant and the bank manager; the court ignored the fact that the customers had parted with their monies without any such intention. Megarry V.-C. clearly regarded it as commendable that the company had acted in this way to protect "members of the public, some of whom can ill afford to exchange their money for a claim to a dividend in the liquidation, and all of whom are likely to be anxious to avoid this". ${ }^{67} \mathrm{He}$ thought the same reasoning would apply whether the customer was purchasing goods or services, but he added the caveat, "different considerations may perhaps arise in relation to trade creditors" .68

It is difficult to be persuaded that this decision is either correct or wise. That the managing director was moved by an altruistic desire to protect the interests of the purchasing public that he could have ignored is no doubt true, but his conduct still surely constituted an improper preference of one class of creditors. Megarry V.-C. thought it sufficient to respond to this objection that the company was not preferring creditors; it was preventing the customers from becoming creditors by making them beneficiaries under a trust. Of course, that line of thinking results in the courts condoning the debtor's amendment of what would otherwise be the statutory order of priority among creditors. Moreover, behind the suggestion that the same might not be permitted with regard to trade creditors lies the assumption that the courts, too, can properly determine those priorities. It must also lead to the conclusion that, though particular funds would normally be paid into the recipient's general bank account, he can keep those funds factually separate, and utilise the trust concept to provide total security for the would-be creditor. In other words, it is so fundamental that trust property is not part of the trustee's own assets that this rule must prevail even though it is the would-be debtor himself who is converting his would-be creditor into a trust beneficiary. ${ }^{69}$

When $\mathrm{A}$ lends money to $\mathrm{B}$ for use in a specified manner only, or $\mathrm{X}$ remits money to $\mathbf{Y}$, a mail order company, as the purchase price of particular goods, to be supplied when available, it is arguable that the trust is not so much providing security coincidentally with the contract of loan or sale, but that the trust precedes the loan or sale. It is a holding device pending the taking effect of the loan or sale. Whether the argument is persuasive is another matter; certainly the transferor of the funds intends an

67. Id. at p. 282 (W.L.R.).

68. Id..

69. It would appear from the reports that Re Kayford Ltd. has neither been followed nor discussed in any Canadian court. 
ultimate loan or purchase when he hands over his funds, but such an argument cannot be made when the trust is employed in the context of merchant financing or the supply of goods on credit. In this situation the financial institution lends money, or the wholesale operator supplies goods on credit, to the dealer or manufacturer, and by the terms of the agreement the dealer or manufacturer is authorised to sell and deliver title in his inventory or product to third party purchasers. The lender or supplier will seek security over the inventory and the proceeds of its retail sale.

Traditionally in common law Canada, this has been done by way of conditional sale or chattel mortgage, either of which creates a security interest in goods supplied or general inventory, and also by way of the assignment of present and future book debts which renders proceeds of sale subject to security. All three of these security transactions are required under provincial law to be registered if they are to be valid, and it is through the notice of registration that third parties are bound by the security interest. In the normal course of business the purchasing customer will not expect to be burdened by the dealer's trade financing, and for this reason alone the security interests of the financing institution or the wholesaler will move from the goods in the dealer's showroom to the proceeds of sale in the dealer's hands.

\section{WHOLESALE FINANCING AGREEMENTS: THE TRUST PROCEEDS CLAUSE}

The trust proceeds clause is an alternative mode of creating a security interest in the proceeds of sale. The financial institution lending funds to the dealer, or the wholesale supplier of goods on credit, will rely upon a clause in the agreement of loan or sale, under which the dealer is designated a trustee to hold the proceeds of sale of the goods in question for the financier or supplier. There are authorities on such clauses stretching back to the beginning of the century, but the leading authority on the validity and effect of the trust was decided only in 1964. In Flintoft $\mathrm{v}$. Royal Bank of Canada 70 the bank had earlier taken a section 88 security over the bankrupt's goods, and also an assignment of the bankrupt's book debts. The assignment, however, was not registered, and therefore only the trust proceeds clause could give the bank security in the book debts which represented the unpaid accounts of purchases of the bankrupt's goods. The Supreme Court held that as soon as these debts were paid the proceeds were the beneficial property of the bank, the bankrupt never had any interest in them, and the assignment merely facilitated the bank's collection of the proceeds. The trust gave the bank all the protection it needed; it did not matter that the assignment was not registered.

This decision in its turn was followed and extended in an interesting manner six years later in the Manitoba Court of Appeal. In Ford Tractor Equipment Sales Co. of Canada Ltd. v. Trustee of Estate of Otto Grundman Implements $L t d .{ }^{71}$ the wholesaler, Ford, entered into a conditional

70. [1964] S.C.R. 631, 47 D.L.R. 141. This security is now established by s. 178 of the Banks and Banking Law Revision Act, S.C. 1980, c. 40.

71. [1970] 72 W.W.R. 1 (Man. C.A.). 
sale agreement with the dealer, Grundman, and the agreement included a trust proceeds clause. In this instance, however, where the dealer was selling tractors, it received used tractors as 'trade-ins' from several of its customers. The title to these used vehicles vested in Grundman, of course, and Grundman's trustee in bankruptcy argued that they were not subject to the trust proceeds clause. In his contention Ford could only obtain title to any such tractor by a bill of sale, duly registered, between Grundman and Ford. This argument was rejected both by the lower court and the Court of Appeal; the trustee in bankruptcy stood in the bankrupt's shoes, and as soon as the bankrupt received title to any 'trade-in', it held that title, because of the trust proceeds clause, on trust for Ford.

Why does the trust have this effect? Why is it able to create an effective security for the lender or the supplier on credit, though there is no registered security transaction in favour of the beneficiary of the trust proceeds clause, or such a registration is incomplete? The immediate answer is that the trust constitutes an alienation of his property rights by the creator of the trust; the trust proceeds clause, as an alienation of the right to future proceeds of sale, implies that those proceeds, if and when the debt arises or the proceeds are paid to the dealer (the trustee), are already the property in equity of the trust beneficiary. It follows, therefore, that, if a trust proceeds agreement is entered into at a time when the dealer is already subject to a registered security transaction, ${ }^{72}$ the dealer no longer has the property rights which he has alienated to the mortgagee or assignee, and as a consequence a purported trust of those rights cannot be created. The trust of those rights fails. One should also notice that where there is no registered security transaction, and the dealer sells an item to a third party customer, no question arises as to the clear title of that third party. A third party purchaser for value without notice of a trust is not bound by the trust in any event. But that rule is not here invoked; the trust attaches to the proceeds of sale, not to the sold item. The trust beneficiary has consented to the third party acquiring a clear title. The issue in these cases, as one can see from the Flintoft and Ford Tractor litigation, is between the lender or supplier (the trust beneficiary) and the dealer (the trustee), though it could be between the lender or supplier and the dealer's mortgagee or assignee under a later chattel mortgage or assignment of book debts, duly registered.

However grave the impact of this trust upon the bankrupt dealer's unsecured creditors, and later secured creditors, it is difficult to see how the case law of trusts can avoid the results of its employment. If it is indeed a trust which the 'trust proceeds clause' creates, and the trust is not struck down by statute or public policy, that must mean that the trust property is effectively alienated by the dealer. Could it be argued that a trust of after-acquired proceeds of sale is invalid as a trust of future property? The answer to that question is, surely, no. Equity regards an agreement for value to hold possible or expected future property on trust, if and when it comes into existence, as an agreement to assign. If the agreement is specifically enforceable, the assignment notionally takes ef-

72. I.e., a conditional sale, chattel mortgage, or assignment of book debts. 
fect as soon as the agreement is made, the property in question being attached when it comes into existence in the assignor's hands. It is clear that the contract between the financier or wholesale supplier on the one hand, and the debtor on the other, is specifically enforceable as to the proceeds of sale of goods to be sold, and the trust is therefore merely completely constituted when the proceeds are acquired by the dealer.

\section{JUDICIAL CHARACTERIZATION OF THE TRUSTS PROCEEDS CLAUSE}

Another issue that the courts have been concerned with is the purpose of this particular 'trust'. Is it strictly a trust in the sense that assets are to be held or administered by a trustee for a beneficiary, or is it essentially a security arrangement?

A trust is a means of holding property for the benefit of another; it is not inherently a security device, like a pledge, a mortgage or a charge. It is certainly not a pledge, which requires possession of the property to be in the pledgee, but it is also conceptually distinct from a charge, or a mortgage by way of a charge, sometimes called an equitable mortgage. An express trust involves a fiduciary relationship between the trustee and the beneficiary, so that the trustee as trustee is barred from taking any benefit in the trust property, ${ }^{73}$ and, though the beneficiary has an interest in the trust property, his remedy is essentially against the trustee for performance of the trust. A chargee on the other hand owns his interest in the charged property, he has no fiduciary relationship with the chargor, and his sole remedy is against the charged property. But, that being said, in practice they can look alike. For instance, the distinction between a bare trust and a charge may be merely in the language of creation. It may even appear that documentation gives rise to both a trust and a charge. It is interesting that in $R e$ Winnipeg Mortgage Exchange Ltd., Wright J. at first instance concluded that the trust documentation itself created an equitable mortgage or charge. ${ }^{74}$

It is said that whether a trust or a charge has been created depends upon the intention of the parties, and this presumably means that, if the parties to an agreement intend to create a trust, they do not intend a charge. However, this hardly adds any clarification to the distinction, unless, like the English court in Re Bond Worth Ltd., ${ }^{75}$ one means by this that it is not a matter of what the parties formally intended to do, but what in substance they intended. Slade $J$. in this English decision held that any agreement for value which, by way of security for the payment of debt, confers an interest in property defeasible on payment of the debt, or which appropriates such property for the discharge of the debt,

73. Unless the instrument provides otherwise.

74. This part of his judgment was not referred to in the judgments of the Court of Appeal. However, Huband J.A. was of the opinion that documentation which purportedly created a trust of a mortgage of a mortgage could not itself create that mortgage of a mortgage. As a consequence the trust failed. See also, supran. 50.

75. [1980] Ch. 228, [1979] 3 All E.R. 919. For a stimulating discussion of this case, and the law in England on this subject, see W. Goodhart and G. Jones, 'The Infiltration of Equitable Doctrine into English Commercial Law' (1980) 43 Mod. L.R. 489. For further references, see Hanbury and Maudsley, Modern Equity, 11 th ed., 1981, p. 663. 
must be regarded as creating a mortgage or charge. This decision must imply that Slade $\mathrm{J}$. would regard the Canadian trust proceeds clause as a mortgage or charge, a characterization that will prevail, whatever the language the parties have used.

Canadian courts to this point have not made this distinction, even though, as in the Ford Tractor case, the defeasibility of the trust on the payment of the sum owed was spelt out in the documentation. Nor have they suggested, though it would seem to be the case, that the trust proceeds clause is an assignment of future book debts. Had they so characterized this clause, they would have brought it within the statutory registration scheme, and surely have solved the problem which the trust proceeds clause presents. The dealer retains the title to the book debts, and the entitlement to receive the proceeds of sale, but from the moment of the agreement taking effect he holds the book debts on trust for the lender or supplier, who acquires the sole beneficial interest in them. Effectively the trust is an assignment of the equitable interest. However, Canadian courts do not appear to have been attracted by the sort of characterization made by Slade J. Instead they have preferred to follow the form of the parties' transaction, and their immediate intention, rather than to ignore those elements and characterize the parties' transaction by the effects which it produces. If the parties have intended a trust, then a trust it is; as such it does not fall within the definition of the transactions, namely, mortgage or assignment of book debts, which the provincial statutes require to be registered.

Indeed, Canadian thinking has been very much inclined to regard the trust as a device which removes the property in question from the reach of the trustee in bankruptcy, however and why ever the trust is created. Both federal and provincial legislation has seized on the trust as a way of putting governmental claims ahead of the unsecured creditors. Section 107(1) of the Bankruptcy Act ${ }^{76}$ provides that, subject to the rights of secured creditors, priority of payment among unsecured creditors shall be in the order therein set out, and a numbering of such creditors, or classes of creditors, from one to nine is then given. Within each class of creditors payment is to be pari passu. The eighth is a class comprising Crown claims when the bankrupt is indebted under a Workmen's Compensation Act, the Unemployment Insurance Act, or the Income Tax Act. This is the first mention in the subsection of Crown claims, whether by right of Canada or any province, and the ninth provides for federal and provincial Crown claims "not previously mentioned in this section.. - pari passu notwithstanding any statutory preference to the contrary".

Since the enactment of the present Bankruptcy Act in 1949 both Parliament and the provincial legislatures, despite the Act, have sought to give pre-eminent priority to a number of claims of their own, or favoured by themselves, and they have done this, or attempted to do it, by way of giving secured status to these claims. The lien, the charge, and the 'deemed trust' have been employed, each created by and deriving its validity from statute. When federal legislation produces such a device, the question is whether that legislation is intended pro tanto to amend the Bankruptcy 
Act. But with provincial legislation the ramifications are more farreaching. Any attempt to give secured status to what would otherwise be a section 107(1) claim raises (or would appear to raise) the constitutional issue of the validity of such legislation, and in 1980 the Supreme Court of Canada in fact held that a provision of this kind in a Quebec Act was invalid. 77 The Act effectively sought by way of a statutory privilege to raise a provincial claim to sales tax from ninth to third place within the order of section 107(1). In a 1982 decision in British Columbia ${ }^{78}$ the same fate overtook a claim on the basis of a deemed trust under the Unemployment Insurance Act ${ }^{79}$ and the Canada Pension Plan Act ${ }^{80}$ of deductions supposed to have been made by an employer on behalf of his employees.

However, it is interesting to observe the preponderant number of cases where the statutory deemed trust has successfully prevailed, and why this has happened. The legislation takes a familiar form; the statute provides that the sum which has been collected from a third party, or deducted from a payment due to a third party, is held on trust either for the Crown or for the person otherwise entitled to the payment, and it is provided that, if the sum has not been kept separate from the assets of the person against whom the claim is made, it is deemed to have been kept separate. The trust is of ten described by the legislation as creating a lien or charge over the assets of the person against whom the claim is made. This is no doubt done because the monies due cannot in fact be recovered under a case law trust remedy where they were not kept separate, and cannot be traced. But to my mind such legislative language suggests very forcibly that the statutory trust, like the lien or charge, is intended to play the role of security over the bankrupt's general assets.

A number of reasons have been put forward by courts which have accepted the validity and efficacy of this type of legislation. ${ }^{81}$ In 1960, in litigation concerning the Ontario Mechanics' Lien Act, Judson J. said for the Supreme Court that, "As to bankruptcy, the creation of the trust [by the Act] does affect the amount of property divisible among creditors, but then so does any other trust validly created". ${ }^{82}$ This is the approach which interprets section $47(a)^{83}$ of the Bankruptcy Act literally, and says

77. Dep. Minister of Revenuev. Rainville [1980] I S.C.R. 35, 105 D.L.R. (3d) 270 ("privileged debt"; retail sales tax due from bankrupt), followed in Re Black Forest Restaurant Ltd. (1981) 47 N.S.R. (2d) 446, 126 D.L.R. (3d) 417 (N.S. App. Div.) (statutory trust of vacation pay in favour of unpaid employees), Re Kinross Mortgage Corp. and Bushell [1982] 1 W.W.R. 87, 127 D.L.R. (3d) 740 (B.C.C.A.), Re Racknagel (1982) 42 C.B.R. (N.S.) 135 (N.S.) (B.C.S.S.).

78. Coopers \& Lybrand Ltd. v. R. (1982) 129 D.L.R. (3d) 582, 32 B.C.L.R. 100 , 39 C.B.R. (N.S.) 247, and additional reasons, 32 B.C.L.R. 71,41 C.B.R. (N.S.) 188 (statutory trust of unemployment and pension plan deductions, and of retail sales tax).

79. S.C. 1970-71-72, c. 48, s. 71(3). See alsos. 71(2).

80. R.S.C. 1970 , c. C-5, s. 24(4). See alsos. 24(3).

81. There has been a considerable number of reported cases on this subject. The latest to date is the decision of Gray J. in Re Phoenix Paper Products Ltd. (1983) 40 O.R. (2d) 321, where, with the exception of very few, the cases are cited by the learned judge, and discussed.

82. John M.M. Troup Ltd. v. Royal Bank of Canada [1962] S.C.R. 487 at 494, 34 D.L.R. (2d) 556 at 572, language expressly followed in Re Airliner Cuisine Inc. (1983) 143 D.L.R. (3d) 154 (Sask.) (statutory trust of wages due or accruing due).

83. S. 47, so far as relevant, reads, "The property of a bankrupt divisible among his creditors shall not comprise, (a) property held by the bankrupt in trust for any other person". 
that, if a trust has been created, even though it be statutory and in certain circumstances merely deemed to exist, the property, whether actual or notional, subject to the trust, is not part of the bankrupt's assets. The majority of the reported decisions has taken this line of reasoning. ${ }^{84}$

A second approach involves an examination of that for which the Crown's legislation is claiming priority. For instance, if the federal authority is claiming from a bankrupt employer the sums which he deducted from employees' wages as their statutorily owed contributions in respect of pension or unemployment benefits, it can be said that those monies, whether or not kept separate by the employer from other assets, are not his monies, but the employees'. This is the argument put forward. Section 47(a) of the Bankruptcy Act, it is implied, recognises these common law property rights of the employee, and the Act in question, such as the Canada Pension Plan Act or Unemployment Insurance Act, is merely relieving the trust beneficiary employee, whose interests are here represented by the Crown, from the hazards of a tracing action. As I have said, such hazards would undoubtedly arise if the employer has not actually segregated the deducted amount, and kept them in a separate account. ${ }^{85}$

It is evident that in this way any deduction from wages, withheld vacation pay, and possibly unpaid wages themselves, can be viewed as the employee's property, rather than a debt owed by the employer to the employee, or to the employer's surrogate, the Crown. And, indeed, this approach has been used to answer the constitutional challenge to such legislation. The statute is concerned, it is said, not with a claim due to the Crown, but to the employee..$^{86}$

84. The Rainville decision of the Supreme Court of Canada (supra $n$. 77) has been consistently distinguished on the grounds that it concerned a statutory lien, and that the exemption of trust property under s. 47(a) of the Bankruptcy Act was not mentioned. See, eg., $R e$ Phoenix Paper Products, supra n. 81. Rainville could hardly have been a decision on liens, because that term is unknown to the law of Quebec, and it would surely be extraordinary for a court concerned with the law of Quebec to mention in that context the position under the legislation of a 'trust' which is essentially a common law concept.

85. In United Association of Journeymen and Apprentices of the Plumbing and Pipefitting Industry v. J. Neilson \& Son (Mechanical) Lid. [1982] 6 W.W.R. 763 (Alta.), the parties had agreed that the employer should deduct union dues from wages. There was no obligation of the employer to hold the moneys separate. As a consequence the employer was a debtor on$l y$, and the union an unsecured creditor.

86. Re Alduco Mechanical Contractors Ltd. (1982) 35 O.R. (2d) 445 (a statutory trust under provincial legislation of vacation pay accruing due to the employee), followed in $R e$ Phoenix Paper Products Ltd., supra n. 81. In Coopers \& Lybrand Inc. v. R., supra n. 78, Taylor J. drew a distinction between "true" and "artificial" statutory trusts. In an ingenious argument he held that deductions required from wages under two federal statutes were "artificial" trusts and did not override the Bankruptcy Act, while the trust of retail sales tax imposed on a vendor under a British Columbia statute was a "true" trust, and therefore fell within s. 47(a) of the Bankruptcy Act as a trust. Unhappily, this ingenuity was not accepted by H.J. MacDonald J. in Att. Gen. of Canada v. Thorne Riddell Inc. [1982] 6 W.W.R. 572, 140 D.L.R. (3d) 740 (Alta.). He was of the view that the deductions owed to the federal Crown, and the retail sales tax owed to the provincial Crown, would both have been debts, but for the statutes in question. These statutes created trusts where there would have been debts. 
Despite the fact that these trusts are clearly security conferring devices and as such should be classified as charges, it is evident that they have met relatively little opposition from the courts. The legislatures have deliberately used the trust in order to put parties, who are to be preferred, ahead of section 107(1), and the courts, from the Supreme Court downwards, have for the most part accepted the trust as a trust whenever the characteristics of a trust are apparent. Despite the presence of these characteristics, they have not been willing to question, as the English court would have done, what is the purpose of the legislation, as opposed to what it has formally sought to achieve.

As a consequence, section 47(a) of our Bankruptcy Act has a more extensive net than has its counterpart under the English legislation. We appear to be more generous in excepting express trusts from having to compete with unsecured creditors, and we extend this same generosity to statutory trusts. Indeed, in one of the recent statutory trust cases which concerned deductions made by the employer from employees' wages for pension and unemployment insurance benefits, the trial judge had this to say: ${ }^{87}$

Whether the trusts established by the two [federal Acts] would be best characterized as 'statutory trusts' or 'express trusts' or as 'constructive trusts' does not . . . af fect the decision in the case at bar. The monies deducted . . . were . . . not property of the employer.

This is how far we have gone in giving effect to the surface characteristics of a trust.

\section{THE CONSTRUCTIVE TRUST}

Those words are also a timely reminder of the significance of the trust which is not express or statutory, but constructive. Whenever the court declares property to be subject to a constructive trust, it is stating that that property, though title be in the name of the person against whom the court order is made, does not properly belong to that person; he holds it for the claimant, to whom it must be surrendered. It follows that constructive trust property, as the trial judge in the above case implied, is not subject to the bankruptcy of the person subject to the order.

As we have seen, ${ }^{88}$ the nature of the constructive trust has recently been declared by the Supreme Court to be a remedy available to the injured party when unjust enrichment has occurred. And unjust enrichment arises, says the Court, when three elements can be established: (1) unjust enrichment of the defendant, (2) a corresponding deprivation of the plaintiff, and (3) an absence of any juristic reason for the enrichment. These three elements exist when the defendant has acquired property as a consequence of fraud, undue influence, or unconscionability, or when he retains property despite clear proof that he acquired it purely as a result of mistake. But, if none of these factors are present, and there was a con-

87. Att. Gen. of Canada v. Thorne Riddell Inc., supra n. 86 at 575 (W.W.R.). For a review of statutory trusts, the criticisms by the Tasse Report, 1970, concerning the use of the 'deemed' trust, and the response of the proposed new Bankruptcy Act, see 'The Crown as Creditor: Priorities and Privileges', Law Reform Commission of B.C., L.R.C. 57, 1982, at 14-15, and 21-27.

88. Supran. 3. 
tract between the plaintiff and the defendant which explains why the property was acquired by the defendant, it is that contract which will determine whether the defendant had a juristic reason for the alleged enrichment. If the contract requires the defendant to carry out some act of transfer in favour of the plaintiff, the terms of the contract will determine what it is the defendant is obligated to transfer. For instance, the defendant may be required to transfer a sum of equivalent value, or specifically to hand over property which he has previously obtained. In the first instance the defendant is a debtor, and in the second a trustee.

This problem arose in Re Ontario Egg Producers' Marketing Board and Clarkson Co. Ltd. ${ }^{89}$ In accordance with a statutory scheme, under which the Board guaranteed a minimum price to producers, egg farmers sold their surplus product to an egg grading station (Whyte \& Son) for an agreed price, and Whyte then sold to the Board for that price plus a margin. Whyte had apparently already assigned its book debts to a bank as security for repayment of a loan ${ }^{90}$ when it received from the Board the proceeds of sale in question. Then, before paying the plaintiff producers, Whyte became bankrupt. The proceeds of sale were paid into court, because both the producers and the bank claimed the monies. Having held that the statutory scheme created no trust in the producers' favour over the funds received by Whyte, and that the circumstances created no resulting trust, $\mathrm{O}^{\prime} \mathrm{Brien} \mathrm{J}$. held there was no constructive trust either. The bank had given consideration for the assignment, and the assignment agreement constituted a juristic reason for the 'enrichment' of the bank. Whyte's trustee in bankruptcy was entitled to an order in his favour.

The inevitable conclusion is that Whyte was a debtor vis-à-vis the producers. Had Whyte itself been a trustee of the monies received from the Board, then it could not have given to the bank an assignment of the right to those monies, and because the producers were unsecured creditors only, it did not matter at what point in time the assignment to the bank took place. It must therefore follow that, if the producers had contested in the bankruptcy that they had priority to the monies received by Whyte from the Board over all the unsecured creditors, they again must have failed. Whyte was not a constructive trustee. As the bank had argued, it was as if producers had sold to a wholesaler, who had in turn sold to a retailer (the Board). It was "a normal business relationship". .91

However, suppose we have a wholesaler selling for credit to a retailer who is empowered by the wholesaler to give good and clear title to third party customers. The agreement between wholesaler and retailer is on a conditional sale basis, and it contains a trust proceeds clause. Suppose also that the court follows $R e$ Bond Worth Ltd., and characterizes the clause as a security device creating a charge. Could the unpaid wholesaler turn the flank of this characterization by arguing that the charge, though unregistered as an assignment of the particular book debt (the right to the proceeds of sale), gives rise to a constructive trust? The argument is that

89. (1982) 125 D.L.R. (3d) 714 (Ont.)

90. There is no mention in the report as to when this assignment took place.

91. Supran. 89 at 716. 
the intent of the parties was that the proceeds upon their origination should be the property of the wholesaler, not of the retailer. Admittedly the wholesaler's title to the proceeds is defeasible upon the retailer paying the wholesaler for the goods supplied, but a defeasible title in this context is a whole title until, if at all, defeasance occurs. As a result of the parties' agreement for value, the retailer, and hence his trustee in bankruptcy, would be unjustly enriched and the wholesaler deprived; neither intended, as evidenced by the clause, that it should be the retailer who would acquire title to the monies, an outcome which would consign the wholesaler to the position of an unsecured creditor.

I suspect that the key to the answer to my question is that the charge should have been registered. The proceeds only become the property of the wholesaler if the charge has been registered. In other words, if the charge is effectively created, the wholesaler has no need of the constructive trust doctrine, and, if it is not, the 'juristic reason for the enrichment' of the retailer is the failure of the wholesaler to register.

However, so long as the trust proceeds clause is seen as creating a true trust, rather than a mortgage or charge, the wholesaler has no need of the constructive trust remedy. There is in existence an express trust. On the other hand, if he did have need of the remedial trust, it surely must be successful, for the results which it can obtain are already available to an express trust beneficiary in an action against his trustee. One turns, therefore, to the contemporary Personal Property Security Acts which have been adopted in Ontario, ${ }^{92}$ Manitoba ${ }^{93}$ and Saskatchewan, ${ }^{94}$ and which are under consideration for adoption in other provinces, including Alberta. These Acts have turned away from security devices, such as conditional sale, chattel mortgage and the assignment of book debts, which are concerned with the whereabouts of title. They adopt instead the principle of section 9 of the Uniform Commercial Code of the United States; this requires the agreement giving security to a party to be registered. Such a perfected security transaction itself provides security against the other party, and third parties acquiring title. The location of title to goods or monies, as between the parties to the agreement, or those persons and third parties, therefore becomes irrelevant.

In this setting the use of a trust to create security, concerned as it is to give the supplier or lender an equitable interest in goods or proceeds of sale, will only be efficacious, like the use of any other security device, if it is registered as a security transaction. And thus the effect of a $R e$ Bond Worth $L t d$. characterization is produced; the trust no longer operates outside the security registration system.

Unhappily, in Re Kryzanowski, ${ }^{95}$ an Ontario decision, this reasoning seems not to have prevailed. The wholesale supplier had a conditional

92. R.S.O. 1980 , c. 375 .

93. S.M. 1973, c. 5 (CCSM, c. P35).

94. S.S. 1979-80, c. P-6.1. For a full discussion of this legislation, see R.C.C. Cuming, 'Second Generation Personal Property Security Legislation', (1981-82), 46 Sask. L.R. 5.

95. (1979) 24 O.R. (2d) 18, 97 D.L.R. (3d) 744, 30 C.B.R. (N.S.) 204. This case appears to have been judicially cited to date on only one reported occasion, see C.T.L. Uniforms Ltd. v. ACIM Industries Lid. (1981) 33 O.R. (2d) 139 at 149-150. 
sale agreement with the retailer, and a security interest under the Ontario Personal Property Security Act. Later, by consenting to a sale, the wholesaler lost his security under the Act. This should have meant that the bank into which the proceeds were paid on the bankruptcy of the retailer should have had a prior claim on these monies to meet outstanding debts owed to the bank by the retailer. However, Steele J. held that the wholesaler retained his interest in the monies, because the agreement contained a trust proceeds clause, and this had the effect of giving the wholesaler sole beneficial interest in the proceeds from the moment of their coming into existence. The trustee in bankruptcy, standing in the shoes of the retailer, therefore had no property interest in the proceeds, and this had to oust the bank.

It may well be that the critics are right, and that this decision will ultimately be held to be an incorrect interpretation of the Act. However, to the present there is no contrary authority under any of the Acts, and we must therefore recognise the problem it poses. If a trust proceeds clause truly creates a trust of the proceeds, as opposed to a charge over the proceeds, it must follow that those proceeds cannot become the property of the indebted retailer until payment of the debt is made by him, and the express or implied condition subsequent of the clause is met. This means that failure to register cannot defeat the beneficiary of such a trust, whether the security legislation is concerned with the whereabouts of title or the registration of security-conferring documentation. As ViceChancellor Megarry has said, ${ }^{96}$ a trust beneficiary claimant does not claim as a creditor at all, whether secured or otherwise.

The conclusion must be that our personal property security legislation will have to expressly include the trust which provides for its own determination on the payment of debt (the beneficiary's interest thereupon being terminated, or upon nonpayment enlarged into an absolute legal title). If the courts instead are to hold that such a trust is subject to the legislation, they will have to be prepared to ignore what the parties to an agreement have formally intended, and instead be concerned with the substance of what the parties have done. The courts are familiar with this approach in the context of tax legislation, where alleged trusts have been characterized as agency. On this occasion the so-called trust may in fact and in substance be a mortgage or charge. The question now is whether this task of characterising trust agreements should continue to be left to the courts. In my view it should not. We need a careful policy consideration of what trusts need to be characterized in this way, and a resultant statutory description (and inclusion within the security legislation) of those trusts only. A statutory solution to the problem would also permit the remedial constructive trust in the context of security transactions to be dealt with at the same time. Our object would be the same - to make the statutory scheme, in particular the personal property security legislation, comprehensive and paramount.

96. Re Kayford Ltd., supra n. 66. 


\section{TRACING AND THE LAW OF SECURED TRANSACTIONS 1. HISTORY}

The doctrine of tracing, though today firmly associated with the law of trusts, originated elsewhere. It was a remedy for the recovery of identifiable property, a remedy which Courts of Chancery made available to any litigant in the Equity jurisdiction who could show that the defendant was a fiduciary vis-à-vis the petitioner and in that capacity was the holder of the legal title to the disputed property. The executor of a will, for instance, was not as such a trustee, but the tracing remedy was available to a will beneficiary, because the Court of Chancery had jurisdiction over the administration of estates. However, once the law of trusts had come to embrace practically all situations of fiduciary property holding, notably through the constructive trust, this remedy became almost exclusively associated with the trust and this is the context in which it is invariably discussed today.

A trust beneficiary has always had the right, whether the trust is express, implied, resulting or constructive, to have the trustee account for the trust property, and, if the trustee has caused any loss or injury to the property or has allowed the same to occur and is in breach of trust in so doing, the beneficiary can require the trustee personally to make good the loss or injury through the payment of compensatory damages. This is the beneficiary's right in personam. But suppose the trustee is insolvent or bankrupt. Or possibly the beneficiary is not interested in obtaining a sum of damages for the trust; he may wish to recover the property asset itself. The trustee may have personally appropriated the property or delivered it to a third party. What then? It is in these circumstances that the beneficiary will invoke the tracing remedy, his right in rem.

The particular value of a right to specific restitution arises when the trustee is bankrupt. Not only can the beneficiary recover for the trust ahead of the trustee's creditors those trust assets which remain in the trustee's name as trustee, he can recover trust assets improperly held by the trustee as his personal property and assets wrongly alienated to any third party, other than the bona fide purchaser of the legal interest who has given value and received no notice. Moreover, despite sale or exchange, he can trace the trust property into the proceeds of sale or to the substituted article. Indeed, he can pursue the trust property through a series of such transactions, assuming none of the third parties in question is a bona fide purchaser for value without notice. What is key, however, is that the trust property continues to be 'identifiable' after the completion of each such transaction as a form of the original entity.

The common law was also in the process of developing such a remedy during the eighteenth and early nineteenth centuries, ${ }^{97}$ but common law actions were never generalised to the point that one clear remedy evolved, and the defendant in a common law action had always the option of returning the monetary value rather than the property itself. What is

97. Scott v. Surman (1742) Willes 400, 125 E.R. 1235; Giles v. Perkins (1807) 9 East. 12, 102 E.R. 477. 
more, the common law did not follow up the eighteenth century precedents in conversion and in money had and/or received, which actually gave priority over the bankrupt's general creditors to the successful plaintiff. But there was yet another factor at work. In the business and commercial setting of the nineteenth century the usual fact situation was that the plaintiff's monies, or the proceeds of sale of his property, had been mixed with the defendant's monies, normally in an active bank account. It became apparent that the common law considered identifiability at an end when the claimant's money was commingled with other monies not belonging to the claimant. Perhaps in time this last objection could have been overcome, ${ }^{98}$ but during that century the superiority of Equity's remedy, which did recognise continued identifiability in commingled funds, became so widely acknowledged that it eclipsed the common law.

On the other hand, the equitable remedy, even today, is not a fully developed concept and has problems of its own. The precedents of Anglo-Commonwealth law are few and there has been much debate among academic writers both as to the elements which make up this remedy, and how the remedy would apply in different situations. ${ }^{99}$ There have also been proposals for reform in the wake of criticism of its scope and applicability. ${ }^{100}$

\section{IDENTIFIABILITY}

The beneficiary of a fiduciary relationship is able to trace and recover the property subject to that relationship so long as the property is identifiable. If fiduciary monies are mixed with monies belonging to other persons, Equity permits the beneficiary to recover the fiduciary monies to the extent only of the lowest intermediate balance of the account, in which the mixing has taken place, between the date the fiduciary monies went into the account and the date the wrongdoing was discovered and the account 'frozen'. In other words, it is a reasonable proposition that any increase in the sum in the account which takes place after the moment of that lowest balance could not have come from the fiduciary monies. As to withdrawals from the account, the fiduciary is assumed to be drawing out his own monies first, but though he is not presumed to be intending to repair breaches of trust when he later pays in money of his own, the beneficiary on behalf of the trust does have a charge upon purchases made by the trustee with account funds. Between beneficiaries of the same trust, or of different trusts, the rule applied is that the source of the first payments in is presumed to determine the ownership of the first sums withdrawn.

98. By the recognition of the claimant's money, assuming they could be quantified, as a chose in action against the bank, as the debtor.

99. See Hanbury and Maudsley, Modern Equity, supra n. 75 at $663-675$, for discussion and footnote reference.

100. In October, 1982, for instance, the British Columbia Law Reform Commission issued a working paper on one particularly controversial aspect of the doctrine, namely, the applicability of the rule in Clayton's Case (1817) 1 Mer. 572, 35 E.R. 781. See 'Competing Rights to Mingled Property: Tracing and the Rule in Clayton's Case', Working Paper No. 36. 
The rule - 'first in, first out' - is also applied as between the beneficiary and the innocent third party donee who receives fiduciary monies already mixed with other monies, or which the innocent donee mixes with his own before learning of the true situation. The third party who receives fiduciary monies knowing, actually or constructively, of the wrongdoing is as culpable and as liable as the wrongdoing trustee himself, but the position of the donee who knew nothing of the source of the monies he received, and dealt with them having no such knowledge, merits careful consideration. He may have so prejudiced himself by his innocent employment of the fiduciary monies that a parity is reached between the equities of the tracing beneficiary and the traced-against donee. At this point tracing stops, even if the beneficiary could reasonably argue that identifiability still exists. If the innocent donee has improved his house with the monies, why should the beneficiary be entitled to require him to mortgage his title to the entire house in order that the beneficiary's claim may be met? Indeed, if the donee has paid his creditors with the money, why should the beneficiary be subrogated to those creditors' rights?

It is not difficult to see in all of this some fairly arbitrary rules of thumb in the determination of what remains identifiable, and some equally rough and ready measures for limiting the possible effects of those rules when they seem to be going too far. This makes one pause and consider the practical implications of this approach in today's world. What are the circumstances today, one asks, in which the tracing remedy is actually being invoked, and is the law on the right track in continuing to afford claimants such a remedy?

There are few Canadian case authorities on the law of tracing, and they follow the English authorities as to the nature and the characteristics of the remedy. ${ }^{101}$ By no means are they limited to claims arising out of breach of express trust, or the administration of deceaseds' estates. They concern fiduciaries both natural and corporate, and a range of fiduciary situations where the fiduciary is insolvent. ${ }^{102}$ However, it is probably fair to say that most Canadian practitioners would find the tracing remedy something which they have rarely met, and that to the Bench it seems merely to involve technical precedents which are not always easy to apply, like the rule in Clayton's Case. It is both for these reasons, and because of the "primitive" 103 state of the Anglo-Canadian remedy, that commercial lawyers are concerned with the provisions of the Personal Property Security Acts ${ }^{104}$ in Canada which apparently introduce the equitable doctrine of tracing into the scheme of that legislation.

101. Waters, D.W.M., The Law of Trusts in Canada, 1974, at 883 et seq.

102. See further, for the commercial context, supra n. 21.

103. Nathan and Marshall, Cases and Commentary on the Law of Trusts, 7th ed., by D.J. Hayton, 1980, at 474.

104. Hereafter referred to as PPSA. 


\title{
3. LEGISLATION
}

The Acts uniformly lay down that a perfected interest in collateral security under the control of a debtor extends to the proceeds of that collateral if the interest of the creditor is further perfected by the registration of a financial statement in the appropriate form, as there set out. It is also provided, however, that proceeds lose that perfected security status when they are no longer "identifiable or traceable". ${ }^{105}$ The significance of this provision can be seen by a reference to the meaning of 'proceeds'. It is defined in the Saskatchewan PPSA, the latest model of such Canadian legislation, as follows: ${ }^{106}$

\begin{abstract}
identifiable or traceable personal property in any form or fixtures derived directly or indirectly from any dealing with the collateral or proceeds therefrom, and includes insurance payments or any other payments as indemnity or compensation for loss of or damage to the collateral or proceeds therefrom, or any right to such payment, and any payment made in total or partial discharge of an intangible, chattel paper, instrument or security; and money, cheques and deposit accounts in banks, credit unions, trust companies or similar institutions are cash proceeds and all other proceeds are non-cash proceeds.
\end{abstract}

All PPSA legislation provides precisely not only what security means, but for the manner in which security may be created, in what circumstances it is binding on third parties dealing with the debtor, and when it loses that effect. It is therefore curious that what is 'identifiable or traceable' is not defined, unless the legislators naturally supposed that it would be read as the term of art developed by the case law. Indeed, since the words, 'or traceable', are added to 'identifiable', it would seem that that is what the legislators must have supposed and intended.

The Uniform Commercial Code, s. 9-306, from which the PPSA is adopted, employs solely the word, 'identifiable', and it would appear that the draftsmen in 1952 intended by this wording to avoid any mention of equitable tracing. Had they characterized the property received by the debtor in place of the original collateral as 'trust' property, or as held by the debtor as a 'constructive trustee', this must have meant that the creditor could have 'traced' the substitute res not only into the hands of the debtor, but also into the hands of third parties. This the draftsmen were evidently anxious to avoid. To say that proceeds exist until they cease to be traceable would be equally undesirable; it directly suggests that the Code envisages the debtor as a constructive trustee. However, if that was the intention of the draftsmen, it was not successfully expressed. 'Identifiability' itself lies at the heart of the tracing remedy, and yet the Code "offers no guidance on how proceeds may be identified" 107 if tracing is not invoked by the Code. Given the inclusion of s. 1-103 which expressly retains the principles of law and equity unless they are displaced by the Code's provisions, American courts have concluded that the Code

105. R.S.O. 1980, c. 375, S. 27(2); S.M. 1973, c. 5, s. 27(3); S.S. 1979-80, c. P-6.1, ss. 2 (ee), 28.

106. Id..

107. Illinois Bar J., February, 1983, p. 382 at 383. 
intends to "permit application of trust law tracing principles to supplement section 9-306". ${ }^{108}$ Such application, as the reported cases show, is now familiar.

The significance of this conclusion as to the meaning of 'identifiable' is that the secured person can follow the proceeds of a disposition of the collateral into commingled funds. Without such a conclusion, 'identifiable' might have appeared to exclude a situation where cash proceeds have been commingled with other funds. In the Canadian PPSA context, however, where 'traceable' is expressly introduced as an alternative to 'identifiable', it is an unavoidable conclusion that the equitable remedy of tracing has been statutorily introduced into the scheme of the legislation. Unlike the American situation where the courts have employed the constructive trust in order to permit the secured creditor to trace into commingled funds, Canadian PPSA jurisdictions do not require any such interpretation of the legislation. Tracing is authorised as a remedy, whether or not a trust exists. ${ }^{109}$

\section{SOME QUESTONS OF POLICY}

This takes us to our second question - is the law on the right track in giving such a remedy to secured creditors? As an American writer has recently argued, ${ }^{110}$ this is a policy matter, and he concludes that it is an acceptable course to permit the secured creditor this remedy. He approves the interpretation of 'identifiable' which has been arrived at by the American courts. I must confess that for the purposes of the Canadian scene I am not persuaded by his reasoning. While it is true that the Canadian commercial scene, like the American, relies heavily on the place of security as a guarantee of protection to financial institutions loaning funds, and large-scale suppliers supplying on credit, there are better ways for regulating competing secured creditors' claims to commingled funds in the bankrupt's hands, or to assets purchased by the bankrupt with the moneys drawn from the commingled pool. As we have seen, the tracing remedy in Anglo-Canadian law provides rough and ready solutions. Surely precise attuned regulation is the whole object of the PPSA legislation.

108. C.O. Fink \& Sons, Inc. v. Sullivan Equipment, Inc. 89 IIl. 2d. 27, 431 N.E. 2d 370, 59 Ill. Dec. 85 (1982), commented upon in Illinois Bar Journal, supra. Other decisions of American courts to the same effect are listed in footnote 6 of the comment, and in a stimulating article on the subject, W.H. Henning, 'Article Nine's Treatment of Commingled Cash Proceeds in Non-Insolvency Cases', (1982), 35 Arkansas L.R. 191. See, especially, pp. 194-195 of this article.

109. It is also arguable, however, that when the PPSA speak of proceeds as identifiable or traceable' personal property, they require the secured party to demonstrate the existence of a fiduciary relationship and an equitable proprietary interest before he can in fact trace. Alternatively, it may now be possible for the secured party to show that an unjust enrichment constructive trust has arisen in his favour; if he has to show that he is entitled under equity doctrine to trace, this may be enough. Given the very novel and undeveloped state of the remedial constructive trust in common law Canada, it is possible that a very large proportion of secured creditors could in this way claim their collateral out of commingled funds. Much depends on how far breach of contract by the debtor is a wrong giving rise to unjust enrichment.

110. Supran. 108. 
Moreover, I am not convinced that enough thought has been given to the unsecured creditor. It is not enough to say he was simply naive or a fool in not requiring security before he supplied goods or services to the debtor. The small company operating in a competitive market situation where customarily security is not sought by traders must of ten take the risk that the debtor will be able to pay his bills. That debtor may well be the dealer whose inventory financing we have been discussing. The dealer as customer does not expect to be asked for security before the goods or the services are supplied, and he will suspect something is amiss with the contractor if he (the customer) is asked for payment, or a significant part of that payment, before any goods are supplied or work is done. For example, the customer will be concerned for his recourse should goods supplied or work done ultimately prove to be shoddy. It has been suggested ${ }^{111}$ that the lowest intermediate balance doctrine is one way in which the tracing remedy attempts to protect the interests of the general creditors, but I suspect this is a generous interpretation of what the Equity courts saw merely as a rational limit to 'identifiability'.112

In my opinion the issue is this: where should identifiability end, and by what method should that end be determined? It is probable that we cannot totally escape from the problems of the identifiability of assets because, except perhaps for the floating charge, until it becomes fixed, that is the essence of security. The creditor points to a specific asset and, aided by registration, asserts that his security is provided by that asset. Moreover, in practice it would probably lessen the value of security immeasurably if identifiability ended once the asset constituting the security is converted into some other form. This would normally happen because of some dealing with it by the debtor contrary to the agreement between the creditor and the debtor, and where as a consequence of silence in the agreement the security is not carried over to the changed nature of the asset. But once the asset, whether in its original or changed form, is mixed as money with monies of the debtor or of others, identifiability is physically artificial beyond that point. Is this then the point at which identifiability should be regarded as at an end? This may well have been the meaning of the draftsmen of the Uniform Commercial Code, because they dealt in detail with all forms of change of the asset other than this, but ignored the commingling of monies.

However, to say that identifiability ceases when monies are commingled leaves it open to the debtor to terminate the creditor's security by his own deliberate act. He may be apprehensive of insolvency and eventual bankruptcy, and convert a security asset. Moreover, acts of such a kind are likely to be motivated by concerns that have a random effect on creditors' interests. Whether it is one creditor or another who is injured will be purely accidental. The same argument, however, can be made about acts of the debtor which change the form of the asset into money,

111. Hanbury and Maudsley, Modern Equity, supran. 75 at 665.

112. I.e., if A's money in the amount of $\$ 1000$ is paid into the fiduciary's general account on Jan. 1, and on May 31 the balance in that account stands at $\$ 100$, on June 1 B's money in the amount of $\$ 1500$ is paid in, and on July $1 \$ 1600$ is withdrawn to purchase an enduring asset, no more than $\$ 100$ of $A$ 's money could possibly have gone into that purchase. 
but do not mix that fund with other monies belonging to the debtor or third parties. I have already conceded that policy no doubt requires that the creditor be entitled to retain his collateral in those circumstances. If that concession must be made, it may be argued, why should not the secured party be free to trace the proceeds of the security into a mixed fund or account?

To my mind this argument is not enough. If the unsecured creditor has a legitimate place in the contemporary commercial scene, then I suggest there is no persuasive reason why the secured creditor should be able to trace in those circumstances when identifiability is recognised in any event to have become artificial. But my objection goes further. As a policy matter the issue is not one solely of identifiability, but of the competing interests of injured creditors. When monies are commingled, surely then we might legitimately look to the conduct of each creditor, and ask ourselves whether any secured party allowed a situation to come about which led to a later creditor misunderstanding the degree of solvency of the debtor. Perhaps we should be concerned with contributory responsibility for loss, as we are concerned with contributory negligence.

Alternatively, if identifiability is to continue to exist when monies are commingled, or something more precise is necessary than contributory responsibility for loss, it may be preferable for legislation to specify in what circumstances identifiability exists. Identifiability aside, the PPSA already defines the meaning of 'proceeds' in very exact terms. ${ }^{113}$ If the task were completed, the legislation could then expressly exclude the applicability of the tracing remedy. For the purposes of personal property security law the controversies associated with that remedy would then in future be avoided. Indeed, it is difficult to resist the conclusion, admittedly with the benefit of a thirty year hindsight, that the draftsmen of the Uniform Commercial Code might usefully have taken this course.

\section{CONCLUSION}

The trust in the setting of business and commerce is now familiar. It has been present in the form of the trust proceeds clause for some years, but today one finds it used for a variety of purposes in all sorts of commercial enterprise, from the oil and gas producing industry of Alberta to the small mortgage broking operation in any part of common law Canada. As a fiduciary and property holding device it has a unique flexibility, because unlike the corporation, it is not a creature of, or closely regulated by, statute. It is popular, as a consequence, not only for the custodial holding of assets and the management of investments, but for the holding of collateral security. However, once the trust is employed outside its traditional area of wills and inter vivos family settlements, a 'Chancery' preserve, it becomes most important that its conceptual nature is both understood and distinguished from other concepts, such as 'debt' at law and 'charge' in equity. Indeed, when circumstances of insolvency or bankruptcy arise, that understanding is essential because assets held in trust by the insolvent or bankrupt are not subject to the

113. R.S.O. 1980 , c. 375 , s. I(r); S.M. 1973 , c. S, s. l(t); S.S. 1979-80, c. P-6.1, s. 2(ee). 
claims of his personal creditors. This divorce between the trust property and the trustee's own assets is crucial to the concept of the trust in the common law system.

In mortgage broking both in practice and in the courts, difficulty has been experienced in understanding how the trust operates as a vehicle for the holding of security. Confusion can arise as to who is the settlor, which assets constitute the trust property, how an express trust is brought into existence, and what a trustee may properly do in the holding and management of the trust property.

In the wholesale financing of inventory, difficulties arise with the trust proceeds clause. Is it a true trust or a charge over future property, enforceable by contract? This question is particularly important in the context of the new personal property security legislation which some provinces have already adopted, and which is planned for Alberta. At the moment, the trust of the proceeds of sale of inventory appears to have effect despite, not in accordance with, that legislation.

The equitable doctrine of tracing, a valuable remedy available to every trust beneficiary, including the constructive trust beneficiary, does appear to be invoked by that legislation. The question has arisen, however, as to what "identifiable or traceable" means. If, as seems an unavoidable conclusion, the doctrine of tracing is invoked, it is important that we understand the effect of this relatively unfamiliar remedy upon the legislative scheme providing for continued security in the 'proceeds' of collateral. It is arguable that this remedy, still rather rudimentary in Anglo-Canadian law, has no place in the detailed scheme the legislation creates.

The potential of the trust as a business or commercial device is considerable, and we can expect to see further significant developments in this area. We could also see growth of the idea, which Lord Denning seems to have entertained, that the distinction between a proprietary right and a personal right is no longer so clear that the former should automatically prevail over the latter. If plaintiff and defendant are both caused loss by the bankruptcy of another, the plaintiff asserting a proprietary right over assets in the bankrupt's hands, and the defendant a mere personal right against the bankrupt, the argument may be advanced that, at least, each should have done all he might reasonably have done to protect his own interests. I have called this contributory responsibility for loss. There is no doubt also that, unless we appreciate the concepts that we are employing, the recent emergence of the unjust enrichment constructive trust could lead in future to some quite extraordinary results.

Taking everything into account, it seems to me urgent that we examine afresh what the trust is, how it is created, how it operates, and what it can achieve in the business and commercial context. We cannot risk false trails. At this point, I have to admit that Dean Weir, sound and seasoned law professor as he was, would probably have approved of a conclusion which involves examining familiar concepts anew. One of his interests was unjust enrichment, but more than that he was a teacher. He revelled in it. I am afraid that we who love to teach are all the same! 